\title{
The Influence of Physical Modification on the Sorption Properties of Geopolymers Obtained from Halloysite
}

\author{
Elżbieta Sitarz-Palczak*, Jan Kalembkiewicz \\ Rzeszow University of Technology, Department of Inorganic and Analytical Chemistry, Faculty of Chemistry, \\ Al. Powstancow Warszawy 6, 35-959 Rzeszow, Poland
}

Received: 26 February 2021

Accepted: 15 May 2021

\begin{abstract}
Halloysite is a naturally occurring mineral that has been listed on the EPA as a material with a low risk of environmental contamination. The aim of the research was to assess the relationship between the adsorption efficiency of selected heavy metals and the effectiveness of physical modification of halloysite. The analyses of selected adsorption and structural properties were carried out, which included, among others, XRD, FT-IR, SEM, and EDS. In addition, a BET and Langmuir isotherm and and the analysis of these isotherms for porous solids (t-Plot method and BJH method) were conducted. On the basis of sorption in the solid-liquid system and leaching tests, the sorption and immobilisation capacity of the studied ions of heavy metals $\mathrm{Cu}(\mathrm{II}), \mathrm{Mn}(\mathrm{II}), \mathrm{Pb}(\mathrm{II})$ and $\mathrm{Zn}$ (II) were also determined. The degree of immobilisation, which determines the susceptibility to the release of the tested ions is approx. $92 \%$. It indicates the possibility of using the obtained geopolymers as a component of mixtures stabilizing industrial waste of various origins. The modification of halloysite through sonification did not significantly change the geopolymerization mechanism, nor did the efficiency of the adsorption processes of the studied $\mathrm{Cu}(\mathrm{II}), \mathrm{Mn}(\mathrm{II}), \mathrm{Pb}(\mathrm{II})$, and $\mathrm{Zn}(\mathrm{II})$ ions and the effectiveness of their immobilization.
\end{abstract}

Keywords: geopolymer, heavy metals, sonification, immobilisation capacity

\section{Introduction}

Clay minerals of the kaolin subgroup are widely used in the industry and environmental protection as absorbents, ion exchangers, and catalysts. The most important member components of the kaolin subgroup

*e-mail: epalczak@prz.edu.pl of minerals are kaolinite and halloysite. The chemical composition of halloysite depends on where it occurs. Deposits of this mineral include Brazil, USA, Japan, France and Poland [1]. Halloysite is a two-layer mineral belonging to the kaolinite subgroup, with a build of layers of silicon tetraeders and aluminium octaedres, between which there is a free space connect valuables by means of chemical bonds. Two main polymorphic varieties of halloysite are known; anhydrous form and hydrated for with spacing interlayers of of 7 or $10 \AA$, 
respectively [2]. The anhydrous form is characterized by the absence of water molecules in the interpack space. Both forms of halloysite are represented by the same chemical formula: $\mathrm{Al}_{2} \mathrm{Si}_{2} \mathrm{O}_{5}(\mathrm{OH})_{4} \cdot n \mathrm{H}_{2} \mathrm{O}$, where $n$ is the number of water molecules that occupy the interlayer space of clay aggregates. The value of $n$ is 0 for kaolinite and up 4 for halloysite [3]. Because of the multilayer structure, most of the hydroxyl groups exist within the lumen and only a few in the outer surface [4]. Halloysite usually takes the form of nanotubes $[5,6]$, also created spherical and flat forms [3, 7]. However, the dominant morphology of halloysite is tube morphology. The charge characteristics of halloysite depend on the $\mathrm{pH}$ value [8]. The clay minerals present a negative charge at $\mathrm{pH}$ higher than 3 owing to the deprotonation of water and hydroxyl groups bound to aluminum and silicon at the edges (Al-OH positive on the outer surface and Si$\mathrm{OH}$ negative on the inner surface). Similar observations on the structure of haloysite are given in the literature $[9,10]$. Halloysite exhibits specific properties which are not observed in other kaolin minerals. These properties play an important role in terms of applications. Moreover, halloysite is commonly used in catalysts and fillers in polymers, plastics, composites, and other similar materials [5, 11-15]. Due to its nontoxicity, it is used in controlled and prolonged release of drugs or bioactive molecules, medical implants, tumor cell isolation, nanoreactors $[16,17]$. In summary, halloysite can be obtained as a promising nanomaterial for the production of various structural and functional materials. To improve the performance of halloysite, surface modification is very desirable. At present, many methods of surface modification of halloysite are reported, including surfactant modification [18, 19], coupling agent modification [20, 21], intercalation modification [22, 23], surface coating modification $[24,25]$, free radical modification [26, 27]. The review of the methods of halloysite modification carried out by various researchers to control the dispersion and phase distribution in polymer matrices was presented in the paper [28]. Clay and clay minerals have also been explored as adsorbents for the removal of heavy metals from aqueous solutions [29-33]. The advantages of using clay minerals as alternative adsorbents for the removal of heavy metals are high ion sorption/exchange capacity, low permeability, swelling ability, chemical and mechanical stability, and large specific surface area [34].

Halloysite is also used to obtain inorganic polymers (geopolymers) - a class of materials obtained by alkaline activation of alluminosillicates [35]. Geopolymers can be synthesized using clay, kaolin, metakaolin, and waste materials such as: coal and biomass ash, slag, and red mud [36-39]. The choice of the materials for obtaining geopolymers depends on factors such as availability of the material, his cost, and type of application [40, 41]. It was found that the structure of alluminosilicate minerals directly influences the synthesis process and properties of geopolymers, and in the case of kaolin, the content of secondary minerals [10]. Examples of the use of halloysite for the synthesis of geopolymers are given in a small number of works, including [10, 13, 42]. According to [35], geopolymeric materials have a wide range of applications in the field of industries such as in automobile and aerospace, non-ferrous foundries, and metallurgy, civil engineering and plastic industries. Moreover, geopolymer technology has long been recognised to provide the potential for immobilisation of hazardous wastes [43] - most for species falling into the vaguely defined category of heavy metals, but also for a wide variety of other elements - ions and compounds [39, 44-46] and other substances like organic compounds [47, 48].

The aim of the research was to assess the relationship between the adsorption efficiency of selected heavy metals and the effectiveness of physical modification of halloysite. Modification of the surface of this mineral by sonication has been made to disturb the surface structure of this adsorbent and thus increase its porosity. The next stage of research was synthesis inorganic polymers from raw halloysite and activated halloysite (after sonication) by geopolymerisation method. The research focused on the effect of synthesis conditions, (temperature, curing time, and the ratio of mass of halloysite to volume of alkaline activator on the microstructure and composition of the geopolymer binder). On the basic of the research investigations, the optimal conditions of geopolimerisation have been determined. The analysis of the structural characteristics of the geopolymers were performed to define the effect of activating halloysite on the geopolymerisation process. Moreover, the examined surface morphology and chemical composition analysis were performed for the obtained geopolymers by SEM-EDS and XRD methods. The changes in the molecular structure of the geopolymers were analyzed using FTIR spectroscopy. In addition, specific surface area measurements were made for the obtained geopolymers (BET isotherm and Langmuir isotherm) and the analysis of these isotherms for porous solids (t-Plot method and BJH method). Additionally, on the basis of the solid- liquid sorption experiment and standard leaching tests (ACTM, TCLP, and USEPA), the sorption and immobilisation capacities of the obtained geopolymers in relation to $\mathrm{Cu}$ (II), $\mathrm{Mn}(\mathrm{II}), \mathrm{Pb}(\mathrm{II})$ and $\mathrm{Zn}(\mathrm{II})$ ions were also determined.

\section{Material and Methods}

\section{Materials Collection and Preparation}

For the study, the raw halloysite was used as a primary component. It originated from the Dunino Mine deposit located in the Lower Silesia, Poland (this is one of some currently exploited deposits of this mineral in the world). Dunino deposit contains over 10 million tons of homogeneous raw material mined using an open pit method. Halloysite extracted from 
this deposit is a product of basalt weathering. The halloysite from the Polish deposit has a plate-tube structure with the dominance of the plate fraction. For the study it was decided to use the modified holloysite, i.e.: one-time sonification using the ultrasonic washer in time $2 \mathrm{~h}$ (power level 250-350 W). The initial ultrasonication enhanced the release of additional aluminum and silicon into the gel phase and strengthening the particle surface bonds. The samples of raw halloysite (refered in article as $\mathrm{H}$ ) and halloysite after sonification - activated halloysite (refered in article as HA) were dried to get ,air-dry" state in laboratory conditions (approx. 2 weeks).

\section{Geopolymers Preparation}

Solid mixtures composed of 50 weight parts of sand and 50 weight parts of raw halloysite $(\mathrm{H})$ or activated halloysite (HA) were prepared. Then, they were dry blended to get a homogeneous mixture for approx. 10 minutes on a laboratory shaker Vibramax 100 (Heidolph, Germany). The alkaline solution was prepared by mixing sodium silicate with molar module $\mathrm{SiO}_{2} / \mathrm{Na}_{2} \mathrm{O}$ 2.4-2.6 and a density of $1.45-1.48 \mathrm{~g} / \mathrm{cm}^{3}$ (Chempur, Poland) with solid $\mathrm{NaOH}$ (reagent analytical grade, Chempur, Poland). It was thoroughly stirred and left to equalize the concentrations and achieve constant temperature (approx. $40 \mathrm{~min}$ ). For the synthesis of geopolymers were used to optimally molar the module $\mathrm{SiO}_{2} / \mathrm{Na}_{2} \mathrm{O}$ aqueous solution of sodium silicate equal to 1.4 , which was obtained by mixing sodium silicate with a solid $\mathrm{NaOH}$ in a ratio of $2: 1$. Then, to the alkaline solution was added a solid mixture (with the addition of sand) and thoroughly mixed. The summary of the synthesis conditions for each sample geopolymer are presented in Table 1. The ratio of alkaline solution to solid part (L:S, $\mathrm{cm}^{3} / \mathrm{g}$ ), was equal, respectively, 30:70, 50:50 (descriptions of the geopolymer are presented in Table 1, respectively: H/30/GEO, H/50/GEO - for raw halloysite and HA/30/GEO, HA/50/GEO - for activated halloysite). The mixing time was approximately 30 minutes. After receive homogeneous ductile consistence, the mixture was transferred to cylindrical molds of plastic material (PE) with dimensions $14 \times 30 \mathrm{~mm}$. The samples were molded using manual pressure and to release air bubbles, the samples were shaken for 15 minutes on a laboratory shaker. Tightly sealed mods were dried at different temperatures under atmospheric pressure or were heated in a laboratory drier (see Table 1). After drying, the molds were removed. To avoid errors when research, three control samples were performed by eliminate the possibility of accidental phenomenon affecting to the final results. Based on the research, it was found that obtaining the desired optimal geopolymer mass consistency is possible for the H/50/GEO and HA/50/GEO geopolymers. Taking into account the synthesis conditions presented in Table 1, the optimal temperature and curing time for these geopolymers are $20^{\circ} \mathrm{C}$ and 15 hours. They were used in the next stages of the research.

\section{Materials Characterization}

SEM (Hitachi S-3400N) equipped with an energydispersive X-ray spectroscopy detector (EDS) was employed to determine the microstructure as well as the chemical composition of the halloysite and geopolymer samples. Preparations were made by placing the samples on a carbon belt with gold sputtering.

The mineralogical compositions of $\mathrm{H}, \mathrm{HA}$, and H/GEO and HA/GEO were assessed by X-ray powder diffraction (XRD). The XRD was conducted on a lowpressure diffractometer SAXS Bruker Nanostar-U. The measurement was made in angular range $\mathrm{CuK} \alpha$ radiation, $0.01-28.1^{\circ}, 0.01^{\circ} 2 \Theta$ step-scan and $5 \mathrm{~s} / \mathrm{step}$, with $\mathrm{Cu}$ anode $\mathrm{CuK} \alpha=1.54 \AA$. The phase identification by Fullprof software, which is based on the Rietvald method.

Nitrogen sorption isotherms of geopolymers were measured with ASAP 2420 (Micromeritics Instrument Corporation, Norcross, USA) apparatus, at a temperature of $196^{\circ} \mathrm{C}$. Prior to the sorption measurements, all samples were degassed at $120^{\circ} \mathrm{C}$ for at least 24 hours at a pressure of $10^{-3} \mathrm{~Pa}$.

The infrared spectra of absorption were recorded at the basic level from $4000-400 \mathrm{~cm}^{-1}$ with a resolution

Table 1. The summary of conditions of synthesis of geopolymers.

\begin{tabular}{|c|c|c|c|c|}
\hline Type of geopolymer & $\begin{array}{c}\text { Ratio L/S } \\
{\left[\mathrm{cm}^{3} / \mathrm{g}\right]}\end{array}$ & $\begin{array}{l}\text { Temperature of curing } \\
{\left[\left[{ }^{\circ} \mathrm{C}\right]\right.}\end{array}$ & $\begin{array}{c}\text { Time of curing } \\
{[\mathrm{h}]}\end{array}$ & Characteristic of blend \\
\hline \multirow{2}{*}{$\mathrm{H} / 30 / \mathrm{GEO}$} & \multirow{2}{*}{$30: 70$} & 20 & 17 & \multirow{2}{*}{$\begin{array}{l}\text { Very liquid consistency of plastic mass, } \\
\text { difficult to form }\end{array}$} \\
\hline & & 40 & 19 & \\
\hline \multirow{2}{*}{$\mathrm{HA} / 30 / \mathrm{GEO}$} & \multirow{2}{*}{$30: 70$} & 20 & 17 & \multirow{2}{*}{$\begin{array}{l}\text { Very liquid consistency of plastic mass, } \\
\text { difficult to form }\end{array}$} \\
\hline & & 40 & 19 & \\
\hline \multirow{2}{*}{$\mathrm{H} / 50 / \mathrm{GEO}$} & \multirow{2}{*}{$50: 50$} & 20 & 15 & \multirow{2}{*}{ Concise consistency of mass, easy to form } \\
\hline & & 40 & 17 & \\
\hline \multirow{2}{*}{$\mathrm{HA} / 50 / \mathrm{GEO}$} & \multirow{2}{*}{$50: 50$} & 20 & 15 & \multirow{2}{*}{ Concise consistency of mass, easy to form } \\
\hline & & 40 & 17 & \\
\hline
\end{tabular}


of $2 \mathrm{~cm}^{-1}$ on Bruker (Germany) FTIR ALPHA spectrometer. Powder preparations for the analysis were made by mixing approx. $0.5 \mathrm{mg}$ of the analyzed sample with $200 \mathrm{mg}$ of spectrally pure $\mathrm{KBr}$. A product in the form of a pill was formed after putting the prepared mixture in vacuum at a pressure of $10 \mathrm{MPa}$.

Chemical analyses (for $\mathrm{Cu}, \mathrm{Mn}, \mathrm{Pb}$, and $\mathrm{Zn}$ ) in the aqueous solutions obtained from the adsorption tests were performed using flame atomic absorption spectrometer Perkin-Elmer 3100 Model (Shelton Instruments, CT USA).

\section{Sorption and Desorption Experiments}

After 28 days, the geopolymer samples were subjected to sorption experiments and leaching tests. To determine sorption properties, the obtained geopolymers were treated with an aqueous solution of $0.1 \mathrm{M} \mathrm{NH}_{4} \mathrm{NO}_{3}$ to remove unreacted $\mathrm{Na}^{+}$ions from their structure, and then with solutions of corresponding metal salts: $\mathrm{ZnCl}_{2}, \mathrm{MnCl}_{2}, \mathrm{CuCl}_{2}, \mathrm{~Pb}\left(\mathrm{NO}_{3}\right)_{2}$ with a concentration of $0.1 \mathrm{~mol} / \mathrm{dm}^{3}$, which represents accordingly $\mathrm{Cu}^{2+}-6354.3, \mathrm{Mn}^{2+}-5490.6, \mathrm{~Pb}^{2+}-20716.4$, and $\mathrm{Zn}^{2+}-65370 \mathrm{mg} / \mathrm{dm}^{3}$. For this purpose, $1.00 \mathrm{~g}$ of powdered geopolymer sample was added to $100 \mathrm{~cm}^{3}$ of $0.1 \mathrm{M} \mathrm{NH} \mathrm{NO}_{3}$ and was shaken thoroughly for 24 hours to Vibramax 100 laboratory shaker $\left(\mathrm{v}=350 \mathrm{rpm}, \mathrm{T}=20^{\circ} \mathrm{C}\right)$. After this time, the separation phase was started by centrifugation $(t=5 \mathrm{~min}$, $\mathrm{v}=2000 \mathrm{rpm}$ ), the obtained precipitates were dried at ambient temperature. $100 \mathrm{~cm}^{3}$ of solutions of the corresponding metal salts: $\mathrm{ZnCl}_{2}, \mathrm{MnCl}_{2}, \mathrm{CuCl}_{2}$, $\mathrm{Pb}\left(\mathrm{NO}_{3}\right)_{2}$ with an initial concentration of $0.1 \mathrm{~mol} / \mathrm{dm}^{3}$ were added to the obtained samples and were then shaken thoroughly for 24 hours under the conditions described above. All experiments were performed without correction of the $\mathrm{pH}$ value of solutions.

The equilibrium adsorption capacity $\left(\mathrm{q}_{\mathrm{e}}, \mathrm{mg} / \mathrm{g}\right)$ and adsorption coefficient (A\%) were calculated as follows:

$$
\begin{gathered}
q_{e}=\frac{\left(C_{0}-C_{e}\right) V}{m} \\
A=\frac{C_{0}-C_{e}}{C_{0}} \cdot 100 \%
\end{gathered}
$$

where:

$\mathrm{C}_{\mathrm{o}}$ and $\mathrm{C}_{\mathrm{e}}$ - the initial and equilibrium metal ion concentration $\left(\mathrm{mg} / \mathrm{dm}^{3}\right)$,

$\mathrm{m}-$ the amount $(\mathrm{g})$ of geopolimer samples,

$\mathrm{V}$ - the volume of solution $\left(\mathrm{dm}^{3}\right)$.

The stability of the bonds between the metal ions and the geopolymers were established on the basis of the standard leachability tests (ASTM, TCLP, USEPA). For this purpose, to the samples after sorption were added $100 \mathrm{~cm}^{3}$ of the leaching solutions: dejonized water $(\mathrm{pH}=6.30)$ or $2.5 \%$ acetic acid $(\mathrm{pH}=4.00)$ or 0.5 $\mathrm{mol} / \mathrm{dm}^{3}$ nitric acid $(\mathrm{pH}=0.60)$. The further procedure was the same as in the sorption experiment described above. Detailed conditions of ACTM, TCLP, and USEPA leaching tests can be found in [49] work.

\section{Results and Discussion}

The obtained geopolymers from halloysite are shown in Fig. 1. It was found that the initial ratio of the volume of the alkaline activator to the content of solids as well as the temperature and time of curing are the factors determining the quality of the obtained product. On the cross- sectional area of the HA/30/ GEO and HA/50/GEO geopolymers for the synthesis of activated halloysite was used, the presence of ,alkaline efflorescence" was observed, which is caused by an excess of sodium hydroxide. Their presence results from the fact that water is contained in the air, penetrates the structure of the geopolymer, and migrates, then evaporates from the surface, leaving alkaline metal cations [50]. They can react with carbon dioxide in air,
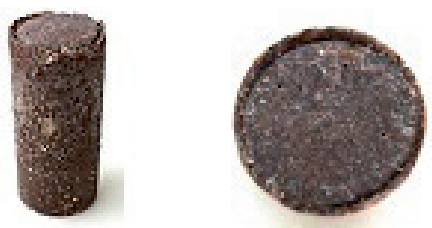

\section{$\mathrm{H} / 30$ GEO}
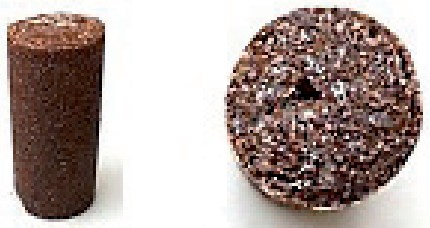

$\mathrm{HA} / 30 / \mathrm{GEO}$

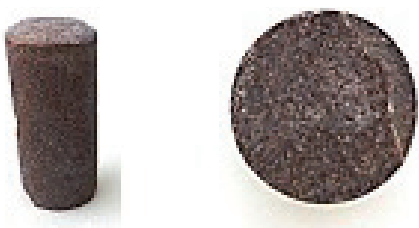

$\mathrm{H} / 50 / \mathrm{GEO}$

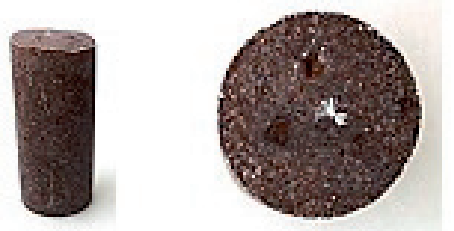

$\mathrm{HA} / 50 / \mathrm{GEO}$

Fig. 1. Geopolymers obtained from raw halloysite (H/30/GEO, H/50/GEO) and activated halloysite (H/30/GEO, H/50/GEO). 
a)

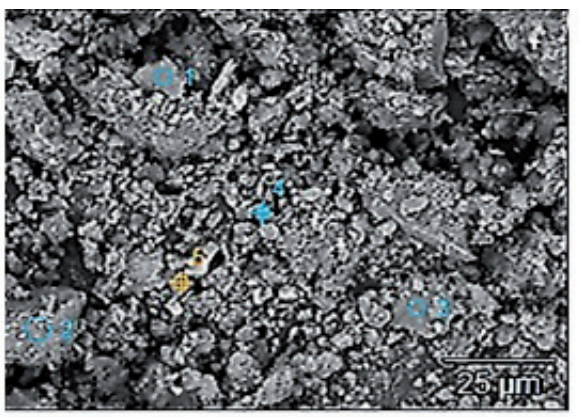

c)

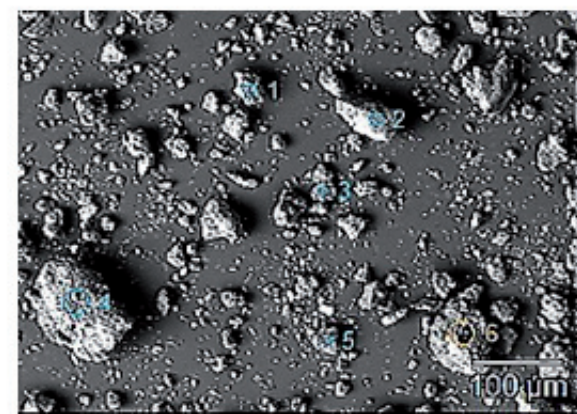

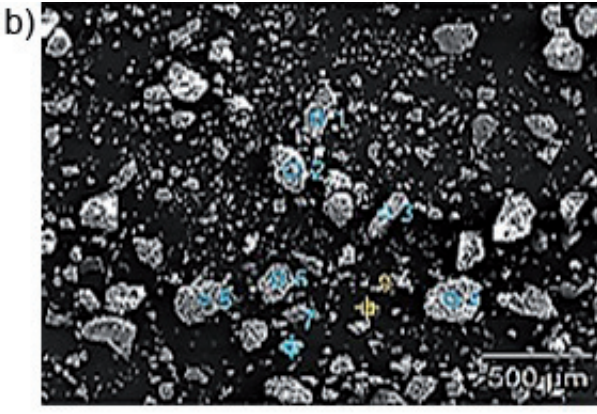

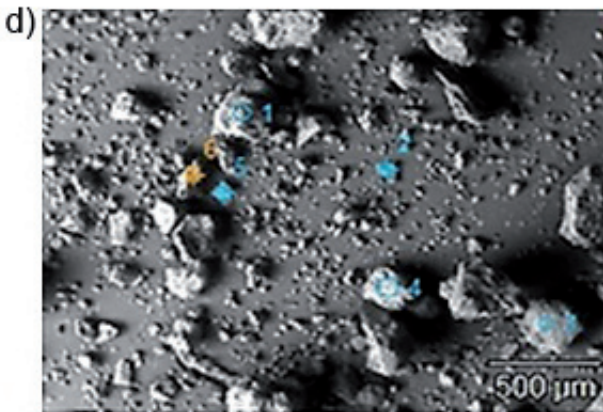

Fig. 2. SEM image of raw halloysite a), activated halloysite b), geopolymer from raw halloysite c), and geopolymer from activated halloysite d).

to form sodium carbonate, the presence of which can lead to the degradation of the geopolymer structure.

\section{Scanning Electron Microscopy (SEM)}

Halloysite as a raw material to obtain geopolymers should not contain high levels of compounds such as sulfur compounds, unburned carbon, free calcium, and iron compounds. If iron is present as hematite or magnetite, it may adversely affect to course of the pozzolanic reaction because they are on the surface of the grains of the material and hinder access of the liquid phase to a glassy phase [51]. In Fig. 2 and Fig. 3 are presented the results of SEM/EDS analysis of the raw halloysite (H) and activated halloysite (HA) and geopolymers obtained from these materials. The products of the geopolymerization reaction are usually heterogeneous materials of complex morphology [52]. Microcracks are visible on their surface, which is attributed to the effect of water evaporation from the geopolymer matrix [53]. SEM studies indicated that the sample of halloysite was uniform in content. In the SEM photos, you can see many agglomerates with the presence of occasional particle tubules (Fig. 2a and Fig. 2b). Both which structure was not consistent. Samples have a granule structure with irregular plates and ranged between $0-4 \mu \mathrm{m}$, averaging $0-1 \mu \mathrm{m}$. The SEM image of the geopolymers (Fig. 2c and Fig. 2d) showed that as a result of geopolymerisation, the structure becomes more porous and open compared a)
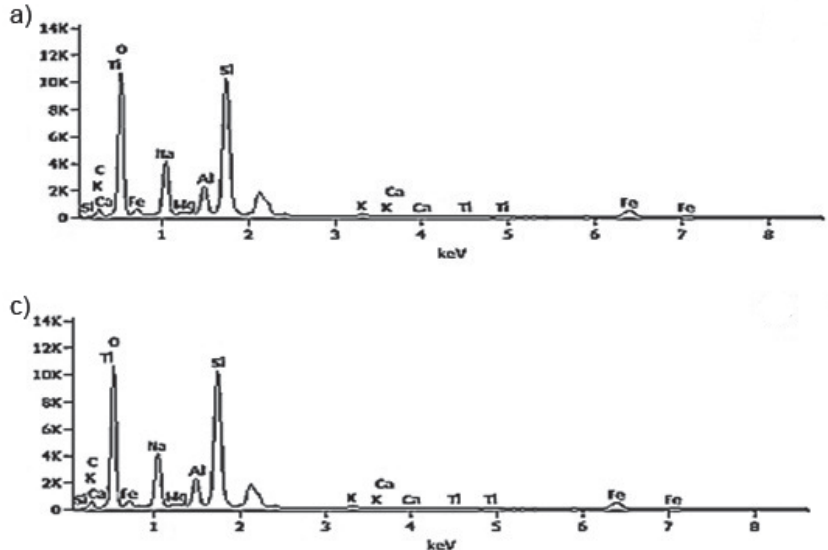

b)

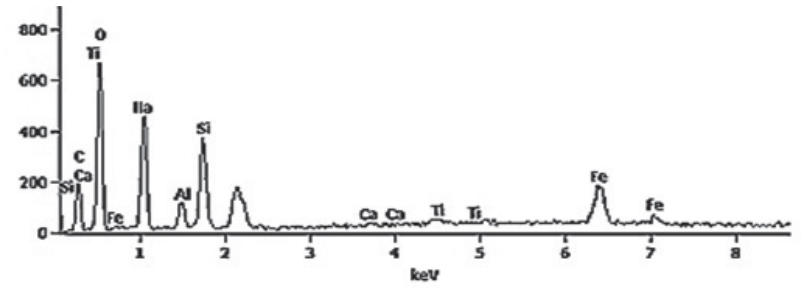

d)

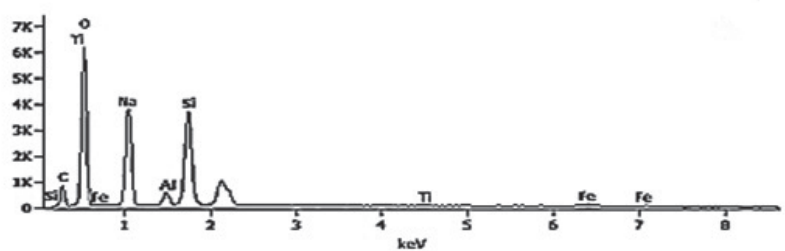

Fig. 3. EDS spectra of raw halloysite a), activated halloysite b), geopolymer from raw halloysite c), and geopolymer from activated halloysite d). 
Table 2. The average composition of the mineral phase of initial samples (H and HA) and geopolymers (H/50/GEO and HA/50/GEO) determined by EDS analysis.

\begin{tabular}{|c|c|c|c|c|c|c|c|}
\hline \multirow{2}{*}{$\begin{array}{c}\text { Type of } \\
\text { samples }\end{array}$} & \multicolumn{7}{|c|}{ Content [\% weight.] } \\
\cline { 2 - 8 } & $\mathrm{Na}_{2} \mathrm{O}$ & $\mathrm{MgO}$ & $\mathrm{Al}_{2} \mathrm{O}_{3}$ & $\mathrm{SiO}_{2}$ & $\mathrm{TiO}_{2}$ & $\mathrm{Fe}_{2} \mathrm{O}_{3}$ & $\mathrm{CaO}$ \\
\hline $\mathrm{H}$ & 0.3 & 0.3 & 31.5 & 45.2 & 1.8 & 8.9 & 0.6 \\
\hline $\mathrm{H} / 50 / \mathrm{GEO}$ & 31.6 & - & 7.8 & 50.2 & 0.5 & 6.8 & 0.6 \\
\hline $\mathrm{HA}$ & 0.3 & 0.3 & 36.6 & 51.8 & 1.9 & 13.6 & 0.6 \\
\hline $\mathrm{HA} / 50 / \mathrm{GEO}$ & 33.6 & - & 6.8 & 52.6 & 0.2 & 5.9 & 0.1 \\
\hline
\end{tabular}

to halloysite (Fig. 2a and Fig. 2b). In the geopolymer structure are dominated aluminosilicates with size larger than $200 \mu \mathrm{m}$. The analysis of EDS spectra of the samples shows the heterogeneous distribution of metals in the grains (Fig. 3a-d).

Table 2 presented the composition of the mineral phase of the raw halloysite $(\mathrm{H})$ and activated halloysite (HA) and geopolymer on the basis of the materials expressed as oxides by EDS analysis. From Table 2 indicated that the $\mathrm{H}$ and $\mathrm{HA}$ samples contain high amounts of aluminium oxide (31.5-36.6\%) and silicon oxide (45.2-51.8\%). It has a low content of magnesium $(0.3 \%)$ and calcium oxide $(0.6 \%)$ and a relatively high content of iron oxide (8.9-13.6\%) and $\mathrm{TiO}_{2}$ (1.8-1.9\%). Analogous results are presented in the work [54]. In comparison to raw halloysite $(\mathrm{H})$, in the obtained geopolymer (H/50/GEO) magnesium oxide did not occur. The same applies to the activation of halloysite (HA) and the geopolymer obtained therefrom, i.e. - HA/50/GEO. The content of aluminium oxide $(7.8 \%)$ and iron oxide $(6.8 \%)$ is much lower in comparison to raw halloysite. The silicon oxide is maintained at a similar level $(50.2 \%)$. The content of calcium oxide in the raw haloysite $(\mathrm{H})$ and in the obtained geopolymer (H/50/GEO) is the same and amounts to $0.6 \%$. The lowest concentration was found with titanium oxide $(0.5 \%)$. In comparison to activated halloysite (HA), in the obtained geopolymer ( $\mathrm{HA} / 50$ / GEO) magnesium oxides do not occur. The content of aluminium oxide $(6.8 \%)$ and iron oxide $(5.9 \%)$ is much lower in comparison to HA. The silicon oxide is maintained at a similar level (52.6\%). The lowest concentration was found with titanium oxide $(0.2 \%)$ and calcium oxide $(0.1 \%)$. In both geopolymers, the presence of sodium oxide was found, which is $31.6 \%$ for $\mathrm{H} / 50 / \mathrm{GEO}$ and $33.6 \%$ for $\mathrm{HA} / 50 / \mathrm{GEO}$, which proves their equal alkalization.

\section{X-ray Powder Diffraction (XRD)}

The XRD patterns of the H, HA, and H-based and HA-based geopolymers are presented in Fig. 4(a-d). The diffraction peaks of the geopolymers do not coincide with those of the precursors ( $\mathrm{H}$ and HA). The raw halloysite $(\mathrm{H})$ shows a broad hump between $20-30^{\circ}(2 \theta)$, the centre being located around $22^{\circ}(2 \theta)$, while in the activated halloysite (HA) at about 12, 20, 22 and $25^{\circ}(2 \theta)$. The geopolymer pattern has shown a broad hump between $5-30^{\circ}(2 \theta)$, the centre being located around: $8,14,17,21,22,25$, and $27^{\circ}(2 \Theta)$; nevertheless the peaks' intensity increases and some crystalline peaks appear as new, which do not coincide with those of the precursors ( $\mathrm{H}$ and HA). This right shift is typically attributed to the formation of new amorphous phases, providing evidence of geopolymerisation occurrence [55].

The analysis of the presented diffractograms confirms the presence of the amorphous phase, which is the main product of geopolymerization. This is evidenced by the elevation of the background in the range of $2 \Theta$ angle in the range of approx. $20-28^{\circ}$. The absence of pronounced peaks indicates the formation of poorly ordered substances such as, for example, the C-S-H phase. The large half-width of the peaks as well as their small number in the diffraction patterns also suggest the formation of mainly amorphous or submicrocrystalline phases during the geopolymerization process.

\section{Characteristics of Geopolymers}

The molar ratios of gepolymers to halloysite are summarized in Table 3. They are analogous to the results described in the work on geopolymers with fly ash from biomass combustion [56]. The products of the geopolymerisation reaction are usually heterogeneous materials with complex morphology [52], which is characterized by the presence of a three-dimensional network of silico- and aluminum-oxygen tetrahedrons bonded together by oxygen bridge atoms. If the $\mathrm{Al}^{3+}$ ion replaces the $\mathrm{Si}^{4+}$ ion, then a negative charge is generated in the network, balanced by $\mathrm{Na}^{+}$cations from the alkaline activator [57]. During the synthesis of geopolymeric materials, special attention should be paid to the water content and a molar ratio of $\mathrm{Al}_{2} \mathrm{O}_{3} / \mathrm{SiO}_{2}$. The value of this molar ratio substantially determines the speed of the activation process and the type of products formed. There are many works available in the literature on the optimization of geopolymer synthesis conditions and modification of the molar ratio $\mathrm{Al}_{2} \mathrm{O}_{3} / \mathrm{SiO}_{2}$ [58-61]. For example, as a result of geopolymerisation with the molar ratio of $\mathrm{Al}_{2} \mathrm{O}_{3} / \mathrm{SiO}_{2}$ $3: 1$, more rigid products will be formed. They can be 
a)

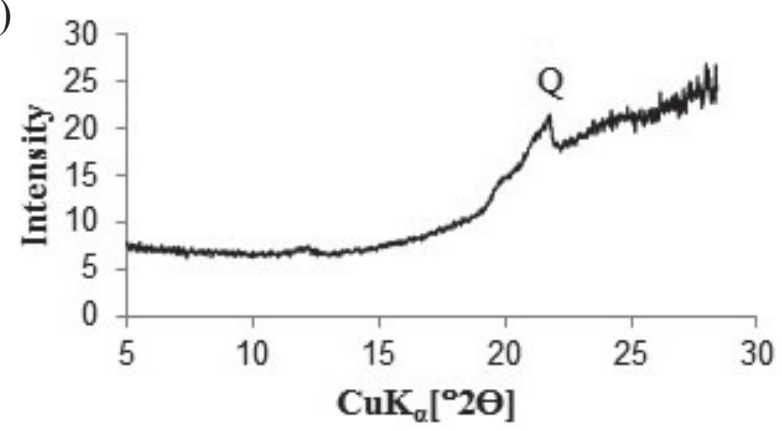

b)

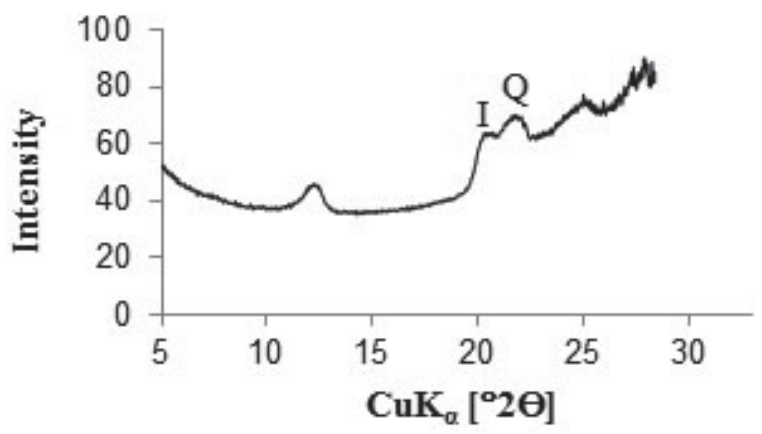

c)

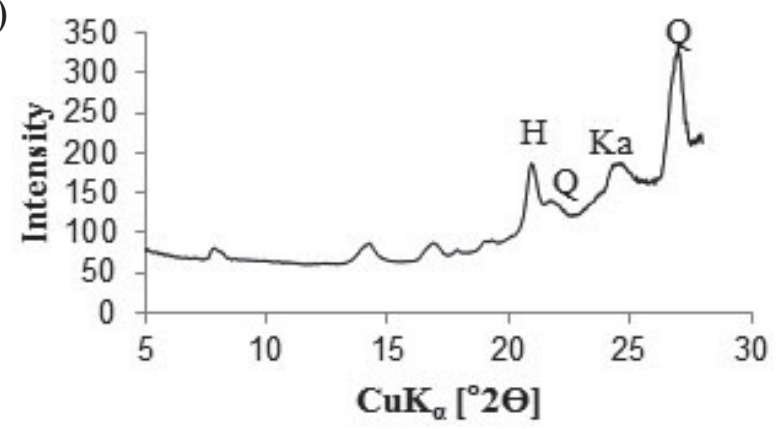

d)

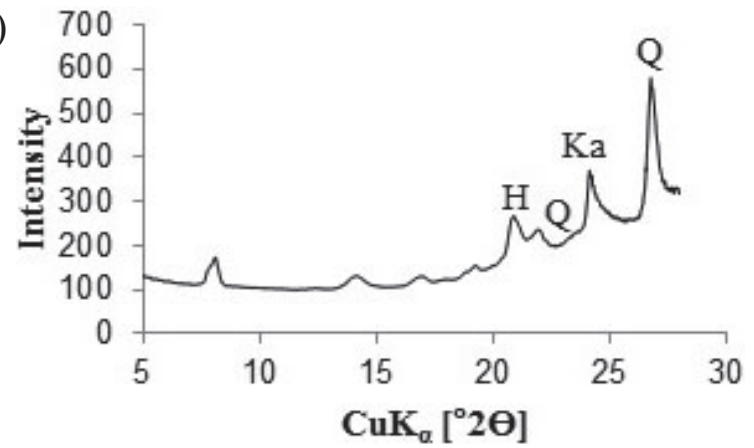

Fig. 4. XRD powder patterns of raw halloysite a), activated halloysite b), geopolymer from raw halloysite c), and geopolymer from activated halloysite d) - description of symbols: Q - quartz, I - illit, H - halloysite, Ka - kaolinite.

used during the preparation of concrete, cement, or waste encapsulation agents. On the other hand, when the molar ratio of $\mathrm{Al}_{2} \mathrm{O}_{3} / \mathrm{SiO}_{2}$ reaches the value above 3, the product is less rigid, more flexible and behaves more like a polymer [62].

The molar ratio of $\mathrm{CaO} / \mathrm{SiO}_{2}$ is 0.2 for the geopolymers based on activated halloysite and 1.1 for the geopolymers based on raw halloysite, respectively. It can therefore be concluded that the synthesis mechanism of these materials was different despite the same calcium content in raw and activated hallysite and the dominant component in the geopolymers obtained from raw halloysite is the C-S-H phase [63]. The C-S-H phase represents hydrated calcium silicates with a low degree of structure order and variable chemical composition, in which the molar ratio $\mathrm{CaO} / \mathrm{SiO}_{2}$ is on average within the range of 0.8-2.0 [64].

The charge on the surface of halloysite affects the initial bounding properties of the mixture. This is due to the dissolution mechanism and the next stage consisting of transporting hydroxyl ions to the halloysite surface. This is followed by hydrolysis and thus new monomers are formed. These monomers then polymerize, forming oligomers of different geometries that form the geopolymeric gel phase. During the pozzolan reaction, an alkaline cation can join the hydrated product. Alkalis are to be considered incorporated into the intermediate layer of the hydrated calcium silicate phase mainly by neutralization of the $\mathrm{SiOH}$ groups. The amount of alkaline hydroxide increases as the molar ratio of $\mathrm{CaO} / \mathrm{SiO}_{2}$ in the mixture decreases. Soluble silicates reduce the leaching of toxic metal ions by the formation of poorly soluble metal oxides and silicates and by encapsulation of these metals in silicates or silica gel [63].

\section{Isotherm of Sorption}

Table 4 shows the results of the porosimetric research. They concern the following parameters of the

Table 3. The molar ratios in composition of geopolymers prepared from raw halloysite $(\mathrm{H})$ and activated halloysite (HA).

\begin{tabular}{|c|c|c|c|c|}
\hline \multirow{2}{*}{ Type of geopolymer } & \multicolumn{5}{|c|}{ Molar ratio } \\
\cline { 2 - 5 } & $\mathrm{Al}_{2} \mathrm{O}_{3} / \mathrm{SiO}_{2}$ & $\mathrm{SiO}_{2} / \mathrm{Na}_{2} \mathrm{O}$ & $\mathrm{Al}_{2} \mathrm{O}_{3} / \mathrm{Na}_{2} \mathrm{O}$ & $\mathrm{CaO} / \mathrm{SiO}_{2}$ \\
\hline $\mathrm{H} / 30 / \mathrm{GEO}$ & 0.70 & 3.45 & 0.49 & 1.07 \\
\hline $\mathrm{H} / 50 / \mathrm{GEO}$ & 0.71 & 5.88 & 0.83 & 1.10 \\
\hline $\mathrm{HA} / 30 / \mathrm{GEO}$ & 0.70 & 3.45 & 0.49 & 0.21 \\
\hline $\mathrm{HA} / 50 / \mathrm{GEO}$ & 0.71 & 5.88 & 0.83 & 0.20 \\
\hline
\end{tabular}


Table 4. Structure parameters of porous structure of geopolymers designated on the basis of low-temperature adsorption and desorption of nitrogen.

\begin{tabular}{|c|c|c|c|c|}
\hline & $\mathrm{H} / 50 / \mathrm{GEO}$ & $\mathrm{HA} / 50 / \mathrm{GEO}$ & HA & $\mathrm{H}$ \\
\hline \multicolumn{5}{|c|}{ Surface area $\left[\mathrm{m}^{2} / \mathrm{g}\right]$} \\
\hline $\begin{array}{l}\text { Single point surface area at } \\
\qquad \mathrm{P} / \mathrm{P}_{\mathrm{o}}=0.249\end{array}$ & 1.53 & 2.22 & 71.46 & 72.59 \\
\hline BET Surface Area & 1.59 & 2.27 & 73.26 & 74.38 \\
\hline Langmuir Surface Area & 2.27 & 3.17 & 101.13 & 102.34 \\
\hline t-Plot External Surface Area & 1.62 & 1.97 & 66.87 & 67.26 \\
\hline \multicolumn{5}{|c|}{ Pore volume $\left[\mathrm{cm}^{3} / \mathrm{g}\right]$} \\
\hline $\begin{array}{l}\text { Single point desorption total pore volume of pores } \\
\text { less than } 805.413 \AA \text { diameter at } \mathrm{P} / \mathrm{P}_{\mathrm{o}}=0.975\end{array}$ & 0.00445 & 0.00639 & 0.15310 & - \\
\hline $\begin{array}{l}\text { BJH Adsorption cumulative volume of pores be- } \\
\text { tween } 17.000 \AA \text { and } 3000.000 \AA \text { diameter }\end{array}$ & 0.00757 & 0.00654 & 0.15032 & 0.14705 \\
\hline $\begin{array}{l}\text { BJH Desorption cumulative volume of pores be- } \\
\text { tween } 17.000 \AA \text { and } 3000.000 \AA \text { diameter }\end{array}$ & 0.00774 & 0.00673 & 0.15865 & 0.15584 \\
\hline \multicolumn{5}{|c|}{ Pore size $[\AA]$} \\
\hline Desorption average pore width (4V/A by BET) & 111.71 & 112.76 & 83.59 & - \\
\hline BJH Adsorption average pore diameter (4V/A) & 191.78 & 115.78 & 86.41 & 84.11 \\
\hline BJH Desorption average pore diameter (4V/A) & 109.77 & 68.89 & 75.16 & 73.61 \\
\hline
\end{tabular}

porous structure of geopolymers: specific surface area, volume, and pore size. Comparing both geopolymers in terms of the obtained BET surface areas, it was found that the HA/50/GEO has a smaller value of BET surface area, equal to $1.59 \mathrm{~m}^{2} / \mathrm{g}$ and $2.27 \mathrm{~m}^{2} / \mathrm{g}$ for the H/50/GEO. The total micropores area determined by the t-method for the H/50/GEO is equal to $1.62 \mathrm{~m}^{2} / \mathrm{g}$, which is about $100 \%$ of the specific surface area, while it is $1.97 \mathrm{~m}^{2} / \mathrm{g}$ for the HA/50/GEO, which constitutes about $87 \%$ of the specific surface area. This is confirmation that the obtained geopolymers are materials with well or very well-developed microporosity.These properties have been confirmed in the works [65-67]. Due to the similar values of the determined structural parameters of both geopolymers, it can be assumed that the mechanism of the metal adsorption process should be similar.

The changes in the porous structure of the tested materials are reflected in the curves of nitrogen adsorption-desorption isotherms. The designated adsorption isotherms (Fig. 5a and Fig. 5b) for both samples analyzed are isotherms type II according to IUPAC. These geopolymers, in addition to the developed microporosity, have a well-developed mesoporosity. According to the literature data, the presence of water in the reaction mixture results in the macroporosity of geopolymers. The macropores can transform into mesopores during the polycondensation of the hydrated geopolymer gel [68].

The use of sonification as a physical modification of the halloysite surface did not affect the values of the structural parameters (see Table 4). However, the effect of geopolymerization is a significant reduction in the specific surface area of geopolymer samples (H/50/GEO and HA/50 GEO) and the pore volume in relation to $\mathrm{H}$ and HA samples. The literature data shows that the surface area and pore capacity of halloysite nanotubes at first improved with treatment time from 1 to 13 hours, and after that it went to fall owing to disaggregation of silica layers [28].

In turn, the size of the pores for the obtained geopolymers increases, as evidenced by the obtained $\mathrm{BJH}$ values. For HA and HA/50/GEO they are equal, 86.41 and $115.78 \AA$, respectively, which is an increase of about $25 \%$. For $\mathrm{H}$ and $\mathrm{H} / 50 / \mathrm{GEO}$ they are equal, 84.11 and $191.78 \AA$, respectively, which is an increase of about $56 \%$. The pore sizes in the geopolymer samples compared to the $\mathrm{H}$ and HA samples were increased from mesopores to macropores. Similar results were obtained for the chemical modification of halloysite with sulfuric acid [69]. The acid reacted from the inner and outer sides by dissolving the octahedral layer $\left[\mathrm{AlO}_{6}\right]$ and rupturing tetrahedral layer $\left[\mathrm{SiO}_{4}\right]$, respectively.

\section{Fourier Transform Infrared Spectroscopy (FTIR)}

Fig. 6 shows the FTIR spectra for the obtained geopolymers from raw halloysite (H/50/GEO) and activated halloysite (HA/50/GEO). By comparing the spectra with each other, you can see their similarity. The spectral bands of the analyzed samples are consistent with the geopolymer spectra characteristics presented by other authors, e.g., [25, 70]. Noteworthy is a very intense band appearing at $970 \mathrm{~cm}^{-1}$, the presence of 
a)

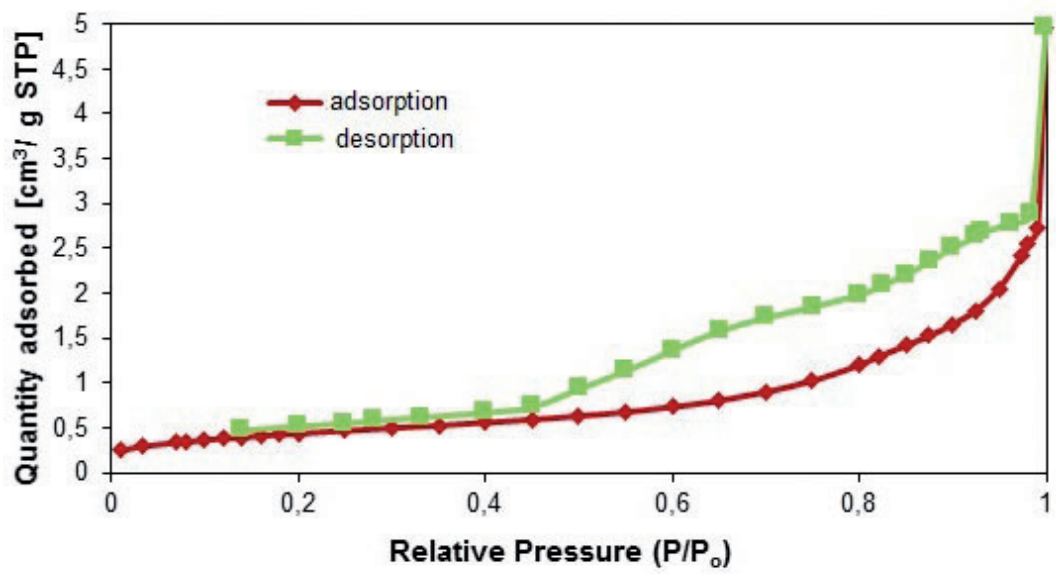

b)

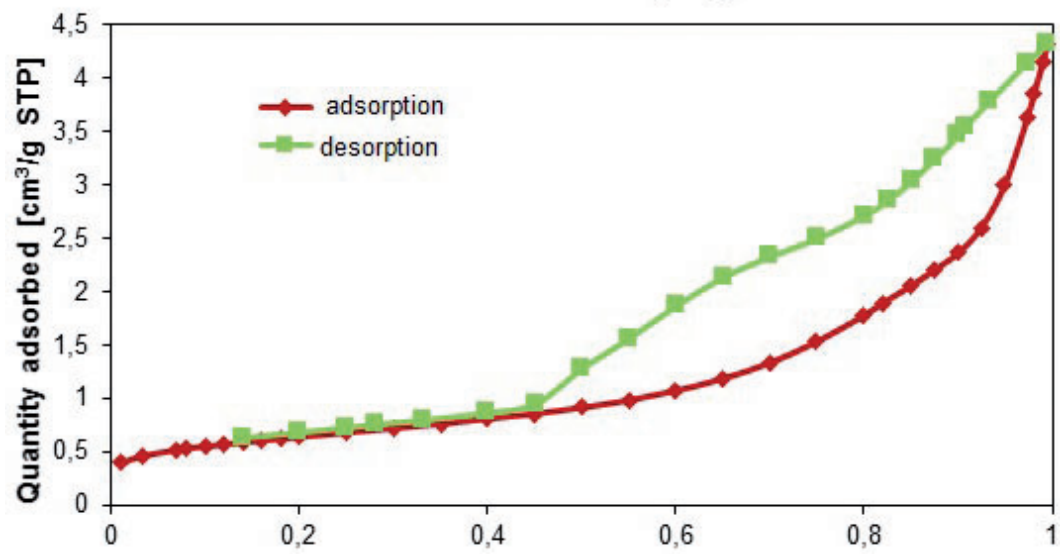

Fig. 5. Adsorption/desorption isotherms of geopolymer from raw halloysite a), and geopolymer from activated halloysite b).

which indicates a low degree of polymerization of the analyzed samples. This band is related to intermolecular vibrations in the tetrahedron $\left[\mathrm{SiO}_{4}\right]^{4-}$ and comes from triple degenerate asymmetric $\mathrm{Si}-\mathrm{O}$ stretching vibrations [71]. The single peak at around $815 \mathrm{~cm}^{-1}$ is characteristic of symmetrical $\mathrm{Si}-\mathrm{O}$ stretching bonds. Its presence is characteristic of the $\mathrm{C}-\mathrm{S}-\mathrm{H}$ phase and indicates an advanced condensation process of the $\left[\mathrm{SiO}_{4}\right]^{4-}$ anion and a high content of the amorphous phase. The presence of this band with higher intensity for $\mathrm{H} / 50$ / GEO compared to HA/50/GEO (see Fig. 6), confirms the presence of C-S-H phase, which is higher for $\mathrm{H} / 50$ / GEO. The relatively large half-width of the most intense bands appearing at 3420 and $970 \mathrm{~cm}^{-1}$ draws attention.

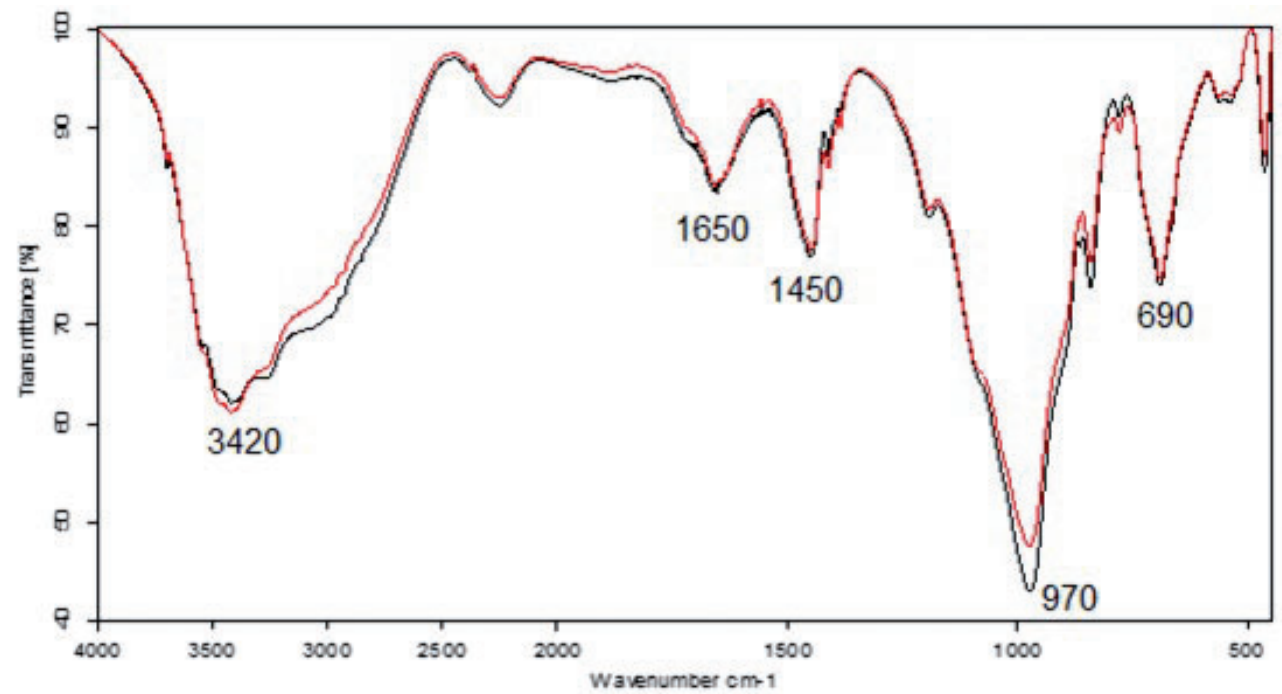

Fig. 6. FT-IR spectra of geopolymers: H/50/GEO - color black and HA/50/GEO - color red. 


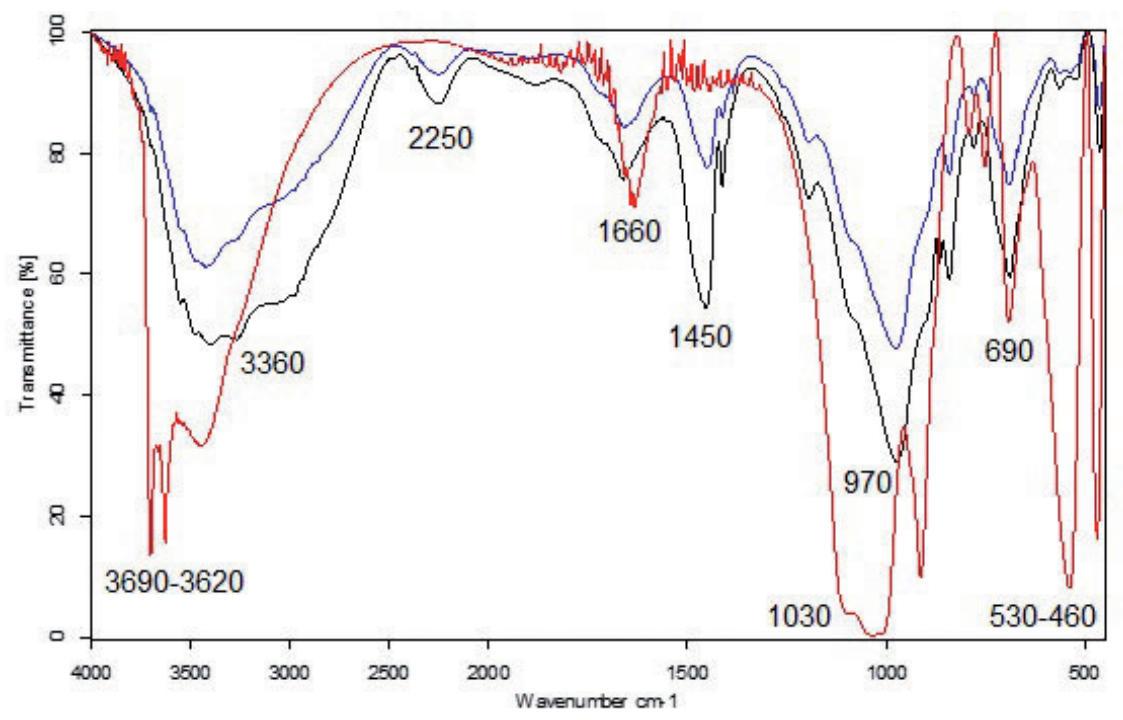

Fig. 7. FT-IR spectra of raw halloysite - color red, geopolymers: H/30/GEO - color black and H/50/GEO - color blue.

This confirms the high degree of amorphousness in the $\mathrm{C}-\mathrm{S}-\mathrm{H}$ phase. The bands in the range of $1450-1400 \mathrm{~cm}^{-1}$ are characteristic of stretching vibrations in carbonates. The presence of the bands at around $1490-1410$ and $880-860 \mathrm{~cm}^{-1}$ indicates the presence of stretching vibrations from the $\mathrm{CO}_{3}^{2-}$ anion, which also indicates the presence of carbonates in the tested samples [72]. The presence of carbonate ions is related to the reaction of atmospheric carbon dioxide with the products of hydration. This fact may also indicate the carbonation of the samples during their synthesis or drying.

In addition, in the spectra shown in Fig. 6 there are also pseudolattice vibrations over tetrahedral structural units appear; range $600-800 \mathrm{~cm}^{-1}$ [73]. The last group of bands is connected with the vibrations of hydroxyl groups, i.e., the wide band that occurs at $3420 \mathrm{~cm}^{-1}$ associated with stretching vibrations of the $\mathrm{OH}^{-}$groups arranged in an orderly manner in the structure, and the second band at around $1650 \mathrm{~cm}^{-1}$ related to the vibrations realized in $\mathrm{H}_{2} \mathrm{O}$ molecules.

To compare the properties of the geopolymers, FTIR spectra of raw halloysite $(\mathrm{H})-$ Fig. 7 and activated halloysite (HA) - Fig. 8 were recorded. Absorption bands at 3695 and $3620 \mathrm{~cm}^{-1}$ in the FTIR spectrum of raw halloysite were assigned to the stretching vibration due to the inner surface of $\mathrm{OH}^{-}$groups of halloysite, respectively [74]. The interlayer water is indicated by the vibration at $1660 \mathrm{~cm}^{-1}$. The $1450 \mathrm{~cm}^{-1}$ peak was assigned to the stretching mode of $\mathrm{C}-\mathrm{O}$, while the band at $1030 \mathrm{~cm}^{-1}$ was caused by the stretching vibration of Si-O-Si. The bands observed at $537-468 \mathrm{~cm}^{-1}$ were due to the vibration of Al-O-Si. The vibration of the inner surface hydroxyl group at $970 \mathrm{~cm}^{-1}$ and $\mathrm{Si}-\mathrm{O}-\mathrm{Si}$ at $470 \mathrm{~cm}^{-1}$ confirmed the existence of the corresponding groups. Very similar results were reported by $[54,74]$.

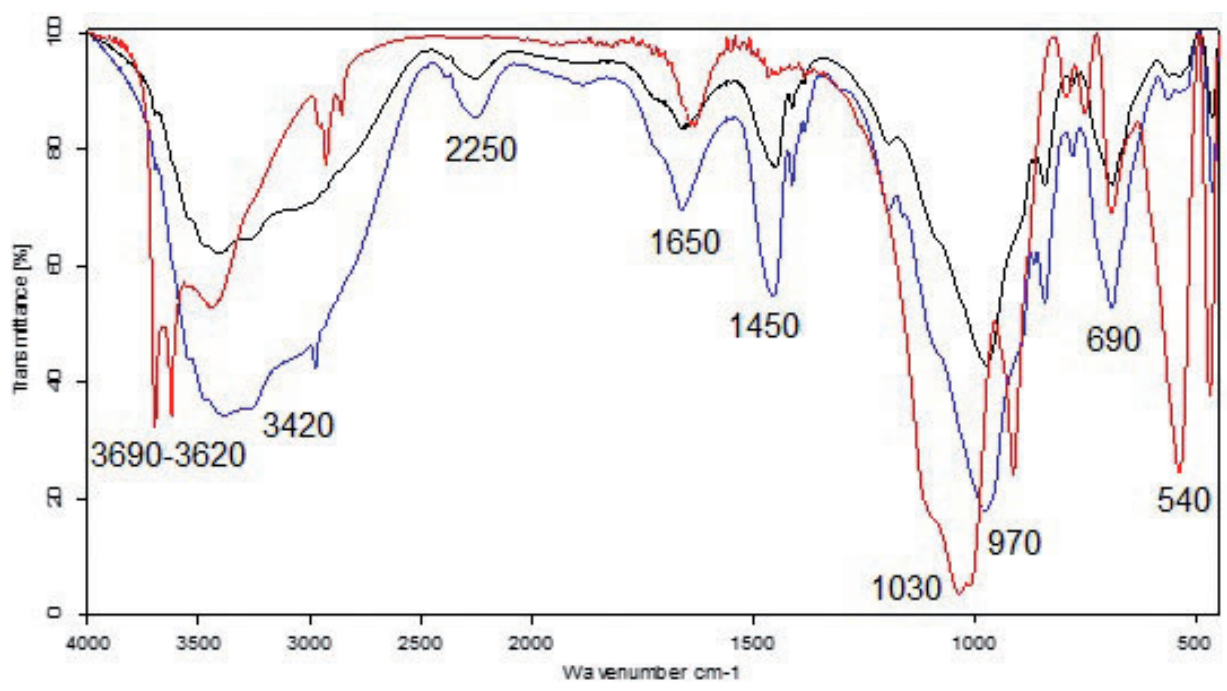

Fig. 8. FT-IR spectra of activated halloysite - color red, geopolymers HA/30/GEO - color blue and HA/50/GEO - color black. 
The bands observed on the spectrum of raw halloysite showed no significant changes in relation to the spectrum of activated halloysite (Fig. 8). The similarity of the spectra for the raw and activated samples of halloysite, nevertheless, proved that the activations by sonification used in this study were not sufficiently high to change the FTIR profiles.

In the FTIR, the spectra of raw halloysite and geopolymer bonds were observed at 3696 and $3621 \mathrm{~cm}^{-1}$ associated with the $\mathrm{OH}^{-}$groups of haloysite, but the intensities changed, suggesting that these $\mathrm{OH}^{-}$ groups were engaged in the interaction between the raw haloysite as well as geopolymers of different extends (Fig. 7). This was ascribed to the existence of H-bonding interactions between the $\mathrm{OH}^{-}$group and water molecules adsorbed on the surface of the geopolymers $\left(\mathrm{Si}-\mathrm{OH} \cdots \mathrm{H}_{2} \mathrm{O}\right.$ and $\mathrm{Al}-\mathrm{OH}^{\cdots} \cdots \mathrm{H}_{2} \mathrm{O}$ ) [55]. The bound around $1660 \mathrm{~cm}^{-1}$ in the spectrum of halloysite, assigned to binding on the surface of the geopolymers of water molecules reduces its intensity and expands for both geopolymers. Beside these, the geopolymer based on halloysite exhibited some new bands, e.g., $1450 \mathrm{~cm}^{-1}$ assigned to the asymmetric stretching vibration $\mathrm{O}-\mathrm{C}-\mathrm{O}$ in carbonic anion, which is formed during atmospheric carbonation on the surface of the geopolymers [55]. On the spectrum of halloysite is a visible band around $1030 \mathrm{~cm}^{-1}$, which is typical of the deformation external vibrations $\mathrm{OH}^{-}$groups and $\mathrm{Si}$ (Al)-O asymmetric stretching vibrations. The band in the spectrum of geopolymers moves in the direction of lower wavenumber values. The bands at $540-470 \mathrm{~cm}^{-1}$ assigned to the vibrations of the tetraedric structures of aluminium or silicon are also disappearing. The FTIR spectra shown in Fig. 8 are analogous to those of the preceding raw haloysite samples without activation and geopolymers, respectively.

\section{Sorption Properties of Geopolymers}

One of the new directions of application of geopolymers is their application as a stabilizing material for the disposal of toxic waste. In the geopolymerisation process, hazardous waste is disposed of at the same time through a physical process (closing the elements in the material) and by building it into the resulting network through chemical reactions. The geopolymer matrix is a good material to immobilize heavy metals, due to its low permeability and resistance to acid and chloride ions. The research in this area has been presented for geopolymers based on ash and kaolin or metakaolin [75-78] report that geopolymers stabilize hazardous waste better than Portland cement. Heavy metals are incorporated into a three-dimensional geopolymer network (usually in the amorphous phase), which reduces their mobility. They can also react with the other components of the geopolymer matrix, creating new phases [79]. Moreover, the $\mathrm{OH}$ functional groups present in the octahedral layer and the oxygen in the tetrahedral layer are able to attach various compounds via hydrogen and van der Waals bonds.

The studied geopolymers based on raw and activated halloysite are characterized by high efficiency of adsorption of $\mathrm{Cu}(\mathrm{II}), \mathrm{Mn}(\mathrm{II}), \mathrm{Pb}$ (II), and $\mathrm{Zn}$ (II) ions. The following values of the adsorption coefficient were obtained for individual ions, which are shown in Table 5. It was found that the efficiency of the adsorption process does not depend on the geopolymers and the value of removal rate is within the range of $93-100 \%$ for each metal ion. The literature data reports confirm the high efficiency of heavy metal ion adsorption with the use of geopolymers obtained from waste materials and aluminosilicate minerals [80-88].

Based on the data obtained by FAAS method concerning the content of metals determined the concentration of metal ions in the solid phase of the geopolymer, as well as the immobilisation coefficient for each metal. The ability to immobilize of metals is the difference between the initial and equilibrium metal ion concentration and the metal ion content in solution after desorption (Table 6). For the studied metal ions, the geopolymers exhibited quite high adsorptive

Table 5. The summary of the adsorption and distribution coefficients of the tested ions after adsorption on the H/50/GEO and HA/50/ GEO geopolymers.

\begin{tabular}{|c|c|c|c|c|}
\hline $\begin{array}{c}\text { Type } \\
\text { of geopolymer }\end{array}$ & $\begin{array}{c}\text { Type of metal } \\
\text { ion }\end{array}$ & $\begin{array}{c}\text { Equilibrium metal ion concentration } \\
\mathrm{C}_{\mathrm{e}}\left[\mathrm{mg} / \mathrm{dm}^{3}\right]\end{array}$ & $\begin{array}{c}\text { Adsorption coefficient } \\
\mathrm{A}[\%]\end{array}$ & $\begin{array}{c}\text { Distribution coefficient } \\
\mathrm{K}_{\mathrm{d}}\left[\mathrm{dm}^{3} / \mathrm{g}\right]\end{array}$ \\
\hline \multirow{4}{*}{$\mathrm{H} / 50 / \mathrm{GEO}$} & 450.00 & 93.00 & 0.01 \\
\cline { 2 - 5 } & $\mathrm{Cu}^{2+}$ & 1.02 & 99.98 & 6.00 \\
\cline { 2 - 5 } & $\mathrm{Mn}^{2+}$ & 828.13 & 96.00 & 0.02 \\
\cline { 2 - 5 } & $\mathrm{Pb}^{2+}$ & 150.00 & 97.82 & 0.04 \\
\hline \multirow{4}{*}{$\mathrm{HA} / 50 / \mathrm{GEO}$} & $\mathrm{Zn}^{2+}$ & 460.00 & 92.85 & 0.01 \\
\cline { 2 - 5 } & $\mathrm{Cu}^{2+}$ & 0.98 & 99.98 & 6.21 \\
\cline { 2 - 5 } & $\mathrm{Mn}^{2+}$ & 837.50 & 95.96 & 0.02 \\
\cline { 2 - 5 } & $\mathrm{Pb}^{2+}$ & 160.00 & 97.67 & 0.04 \\
\hline
\end{tabular}


Table 6. The content of the tested ions after desorption from the H/50/GEO and HA/50/GEO geopolymers determined by the FAAS method.

\begin{tabular}{|c|c|c|c|c|}
\hline $\begin{array}{c}\text { Type } \\
\text { of geopolymer }\end{array}$ & $\begin{array}{l}\text { Type of metal } \\
\text { ion }\end{array}$ & $\begin{array}{l}\text { Leaching } \\
\text { solutions }\end{array}$ & $\begin{array}{l}\text { Concentration metal ion for unit mass of sorbent } \\
\qquad \mathrm{C}_{\mathrm{s}}[\mathrm{mg} / \mathrm{g}]\end{array}$ & $\begin{array}{c}\text { Immobilisation coefficient } \\
{[\%]}\end{array}$ \\
\hline \multirow{12}{*}{$\mathrm{H} / 50 / \mathrm{GEO}$} & \multirow{3}{*}{$\mathrm{Cu}^{2+}$} & $\mathrm{H}_{2} \mathrm{O}$ & 5.98 & 92.98 \\
\hline & & $\mathrm{CH}_{3} \mathrm{COOH}$ & 5.97 & 92.82 \\
\hline & & $\mathrm{HNO}_{3}$ & 5.97 & 92.83 \\
\hline & \multirow{3}{*}{$\mathrm{Mn}^{2+}$} & $\mathrm{H}_{2} \mathrm{O}$ & 6.09 & 99.96 \\
\hline & & $\mathrm{CH}_{3} \mathrm{COOH}$ & 6.09 & 99.97 \\
\hline & & $\mathrm{HNO}_{3}$ & 6.09 & 99.97 \\
\hline & \multirow{3}{*}{$\mathrm{Pb}^{2+}$} & $\mathrm{H}_{2} \mathrm{O}$ & 19.92 & 95.87 \\
\hline & & $\mathrm{CH}_{3} \mathrm{COOH}$ & 19.89 & 95.73 \\
\hline & & $\mathrm{HNO}_{3}$ & 19.89 & 95.72 \\
\hline & \multirow{3}{*}{$\mathrm{Zn}^{2+}$} & $\mathrm{H}_{2} \mathrm{O}$ & 6.73 & 97.79 \\
\hline & & $\mathrm{CH}_{3} \mathrm{COOH}$ & 6.72 & 97.63 \\
\hline & & $\mathrm{HNO}_{3}$ & 6.72 & 97.62 \\
\hline \multirow{12}{*}{$\mathrm{HA} / 50 / \mathrm{GEO}$} & \multirow{3}{*}{$\mathrm{Cu}^{2+}$} & $\mathrm{H}_{2} \mathrm{O}$ & 5.97 & 92.84 \\
\hline & & $\mathrm{CH}_{3} \mathrm{COOH}$ & 5.96 & 92.65 \\
\hline & & $\mathrm{HNO}_{3}$ & 5.96 & 92.67 \\
\hline & \multirow{3}{*}{$\mathrm{Mn}^{2+}$} & $\mathrm{H}_{2} \mathrm{O}$ & 6.09 & 99.96 \\
\hline & & $\mathrm{CH}_{3} \mathrm{COOH}$ & 6.09 & 99.97 \\
\hline & & $\mathrm{HNO}_{3}$ & 6.09 & 99.97 \\
\hline & \multirow{3}{*}{$\mathrm{Pb}^{2+}$} & $\mathrm{H}_{2} \mathrm{O}$ & 19.91 & 95.78 \\
\hline & & $\mathrm{CH}_{3} \mathrm{COOH}$ & 19.88 & 95.70 \\
\hline & & $\mathrm{HNO}_{3}$ & 19.89 & 95.68 \\
\hline & \multirow{3}{*}{$\mathrm{Zn}^{2+}$} & $\mathrm{H}_{2} \mathrm{O}$ & 6.73 & 97.65 \\
\hline & & $\mathrm{CH}_{3} \mathrm{COOH}$ & 6.71 & 97.49 \\
\hline & & $\mathrm{HNO}_{3}$ & 6.71 & 97.49 \\
\hline
\end{tabular}

capacity, especially for $\mathrm{Pb}^{2+}(19.9 \mathrm{mg} / \mathrm{g})$, following the order $\mathrm{Pb}^{2+} \gg \mathrm{Zn}^{2+} \approx \mathrm{Mn}^{2+}>\mathrm{Cu}^{2+}$. To determine the extent to which the metal ion is connected to the solid phase of the geopolymer, we calculated values of the distribution coefficients between the solid - aqueous solutions. The distribution coefficient $\left(\mathrm{K}_{\mathrm{d}}\right)$, which means the ratio of the adsorbed metal ions and the residual ions in the solution, can indicate the selectivity of an adsorbent. In a specific adsorbate and adsorbent system, a higher $\mathrm{K}_{\mathrm{d}}$ value for a metal ion means it has a higher selectivity for adsorption [89]. The distribution coefficients $\left(\mathrm{K}_{\mathrm{d}}\right)$ were calculated as follows:

$$
K_{d}=\frac{C_{s}}{C_{e}}
$$

where:

$\mathrm{C}_{\mathrm{s}}$ - the total concentration of each metal cation in unit mass of sorbent $(\mathrm{mg} / \mathrm{g})$,
$\mathrm{C}_{\mathrm{e}}$ - the concentration of each metal cation in water solution in equilibrium state $\left(\mathrm{mg} / \mathrm{dm}^{3}\right)$.

The results are given in Table 5. Based on these results, it found that the immobilisation coefficient in each test system exceeded $92 \%$ and its value does not depend on the used geopolymers; it is related to the type of metal. The highest value of the immobilisation coefficient was obtained for manganese ions, the lowest for cooper ions. In addition, the $\mathrm{pH}$ values of the leaching solution did not significantly affect the amount of removed metals. A very small change in the immobilization factor was observed with a decrease in $\mathrm{pH}$ of the liquor solution; e. g., for zinc, it has $0.17 \%$. This means that despite the increasing aggressiveness of the leaching solution, the concentrations of the metals leached in the solid phase remain at the same level (Fig. 9). This indicates the permanent immobilisation of the tested metals in the $\mathrm{Si}$ Al structure of the obtained geopolymers. In the 

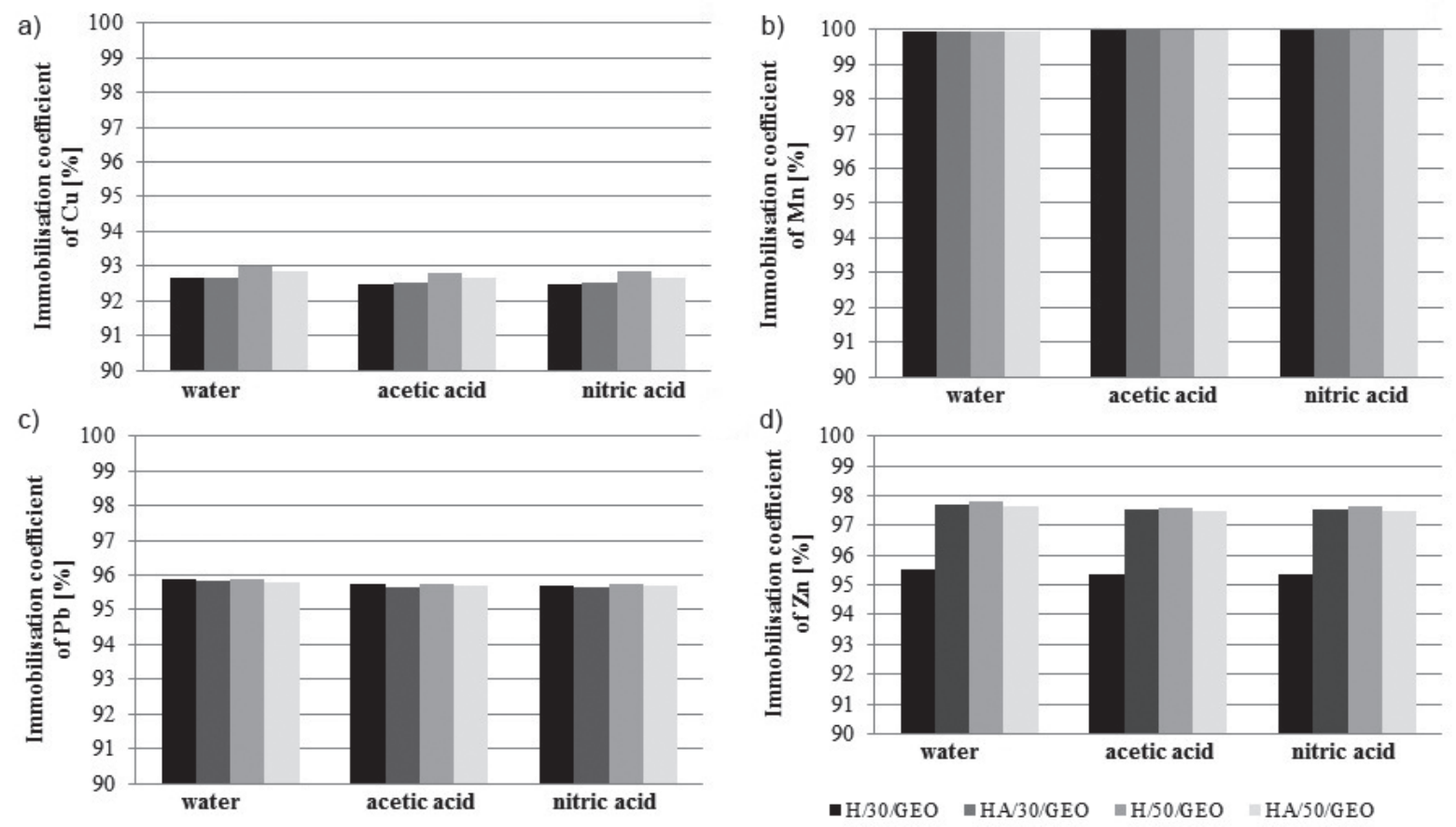

Fig. 9. Comparison of the values the immobilisation coefficients on the H/30/GEO, HA/30/GEO, H/50/GEO and HA/50/GEO for the tested metals: $\mathrm{Cu}$ a), $\mathrm{Mn} \mathrm{b}$ ), $\mathrm{Pb}$ c), and $\mathrm{Zn} \mathrm{d}$ ) depending on used of the leaching solutions: $\mathrm{H}_{2} \mathrm{O}_{,} \mathrm{CH}_{3} \mathrm{COOH}, \mathrm{HNO}_{3}$.

halloysite based geopolymeric matrix, $\mathrm{Pb}$ shows better immobilization efficiency than $\mathrm{Cu}$, probably because the ionic radius of $\mathrm{Pb}$ and $\mathrm{Cu}$ are different, or $\mathrm{Cu}$ and $\mathrm{Pb}$ have different roles in the synthesis of the halloysite based geopolymeric matrix. The value of the distribution coefficient $\left(\mathrm{K}_{\mathrm{d}}\right)$ is directly proportional to the concentration of the metal in the solid phase $\left(\mathrm{C}_{\mathrm{S}}\right)$, hence analogous dependencies were obtained in relation to this parameter. Each of the geopolymers (H/50/GEO and $\mathrm{HA} / 50 / \mathrm{GEO}$ ) obtained have identical distribution coefficient values for the same metal ions. Namely, the $\mathrm{Kd}$ values in relation to zinc and lead ions are identical for both obtained geopolymers, which indicates that their immobilisation properties are practically the same for these ions. The highest $\mathrm{K}_{\mathrm{d}}$ value was obtained for manganese ions $\left(6.21 \mathrm{dm}^{3} / \mathrm{g}\right)$, this is also confirmed by the highest immobilisation coefficient value for these ions equal to $99.97 \%$.

\section{Conclusions}

This paper investigated the assessed feasibility of geopolimers synthesis from raw and activated halloysite by geopolymerisation method. Assessed the studies performed, it was found that obtaining the desired dense plastic consistency of received geopolymers is possible under the following conditions, which are indicated as optimal: temperature $20^{\circ} \mathrm{C}$, curing time 15 hours and the ratio of halloysite [g] to alkaline activator $\left[\mathrm{cm}^{3}\right]-50: 50$. The obtained geopolymers have a similar morphological structure, phase composition, and show a high degree of amorphousness. It was found that the geopolymerisation mechanism is not identical because the C-S-H phase is probably present only in goepolymers synthesized from raw halloysite. Clear confirmation of its presence requires in-depth research using X-ray diffraction (XRD).

The study of sorption properties and the ability to immobilize selected heavy metals cause that the obtained geopolymers may be excellent components of any blends, including blends stabilizing industrial waste of various origins. Furthermore, they can be used to isolate and seal landfills for this type of waste. Studies have shown that geopolymers based on raw and activated halloysite can radically reduce the leachability of heavy metals and bind them permanently in a geopolymer matrix. The modification of halloysite through sonification did not significantly change the geopolymerization mechanism, nor did the efficiency of the adsorption processes of the studied $\mathrm{Cu}(\mathrm{II}), \mathrm{Mn}(\mathrm{II})$, $\mathrm{Pb}(\mathrm{II})$, and $\mathrm{Zn}(\mathrm{II})$ ions and the effectiveness of their immobilization.

To establish the use of geopolymers obtained from halloysite as heavy metal remediation materials, more investigations are required to determine the standard dose of geopolymers for the adsorption of heavy metals.

\section{Acknowledgements}

The authors acknowledged the PTH Intermark for halloysite samples. 


\section{Conflict of Interest}

The authors declare no conflict of interest.

\section{References}

1. WILSON M.I. Weathering of the primary rock-forming minerals: processes, products and rates. Clay Miner. 39 (3), 233, 2004.

2. VEERABADRAN N.G., PRICE R.R., LVOV Y.M. Clay nanotubes for encapsulation and sustained release of drugs. Nano 2, 115, 2007.

3. JOUSSEIN E., PETIT S., CHURCHMAN J., THENG B., RIGHI D., DELVAUX B. Halloysite clay minerals - A review. Clay Miner. 40 (4), 383, 2005.

4. YANG Y., CHEN Y., LENG F., HUANG L., WANG Z., TIAN W. Recent advances on surface modification of halloysite nanotubes for multifunctional applications. Appl. Sci. 7, 1215, 2017.

5. PASBAKHSH P., CHURCHMAN G.J., KEELING J.K. Characterisation of properties of various halloysites revelant to their use as nanotubes and microfiber fillers. Appl. Clay Sci. 74, 47, 2013.

6. VERGARO V., LVOV Y.M., LEPORATTI S. Halloysite clay nanotubes for resveratrol delivery to cancer cells. Macromol. Biosci. 12 (9), 1265, 2012.

7. LEVIS S.R., DEASY P.B. Characterisation of Halloysite for Use as a Microtubular Drug Delivery System. Int. J. Pharm. 243 (1-2), 125, 2002

8. CHURCHMAN G.J., PASBAKHSH P., LOWE D.J., THENG B.K.G. Unique but diverse: some observations on the formation, structure and morphology of halloysite. Clay Miner. 51 (3), 395, 2016.

9. HUANG B., LIU M., ZHOU C. Cellulose-halloysite nanotube composite hydrogels for curcumin delivery". Cellulose, 24 (8), 2861, 2010.

10. ZHANG Z., WANG H., YAO X., ZHU Y.. Effects of halloysite in kaolin on the formationand properties of geopolymers. Cem. Concr. Compos. 34 (5), 709, 2012.

11. ROOJ S., DAS A., THAKUR V., MAHALING R.N., BHOWMICK A.K., HEINRICH G. Preparation and properties of natural nanocomposites based on natural rubber and naturally occurring halloysite nanotubes. Mater. Des. 31 (4), 2151, 2010.

12. FU Y., ZHANG L. Simultaneous deposition of Ni nanoparticles and wires on a tubular halloysite template: A novel metallized ceramic microstructure. J. Solid State Chem. 178 (11), 3595, 2005.

13. BARRIE E., CAPPUYNS V., VASSILIEVA E., ADRIAENS R., HOLLANDERS S., GARCÉS D., PAREDES C., PONTIKES Y., ELSEN J., MACHIELS L. Potential of inorganic polymers (geopolymers) made of halloysite and volcanic glass for the immobilisation of tailings from gold extraction in Ecuador. Appl. Clay Sci. 109-110, 95, 2015.

14. MACKENZIE K.J.D., BREW D.R.M., FLETCHER R.A., VAGANA R. Formation of aluminosilicate geopolymers from 1:1 layer-lattice minerals pre-treated by various methods: comparative study. J. Mater. Sci. 42, 4667, 2007.

15. ZHAO Y., THAP S., WEISS L., LVOV Y.M. Phase change insulation for energy efficiency based on wax-halloysite composites, in: 2nd International Conference on Structural Nano Composites (NANOSTRUC 2014) IOP Conference
Series, IOP Publishing, Materials Science and Engineering 64, 012045, 2014.

16. KAMBLE R., GHAG M., GAIKAWAD S., PANDA B.K. Halloysite nanotubes and applications: a review. J. Adv. Scient. Res. 3 (2), 25, 2012.

17. SKIBIŃSKA M. The sorption capability of halloysite. Annales Universitatis Mariae Curie-Skłodowska, Lublin Polonia: Section A 72, 47, 2017.

18. CAVALLARO G., LAZZARA G., MILIOTO S., PARISI F. Hydrophobically Modified Halloysite Nanotubes as Reverse Micelles for Water-in-Oil Emulsion. Langmuir 31 (27), 7472, 2015.

19. TULLY J., YENDLURI R., LVOV Y.M. Halloysite Clay Nanotubes for Enzyme Immobilization. Biomacromol. 17 (2), 615, 2016.

20. GUO B., ZOU Q., LEI Y., JIA D. Structure and Performance of Polyamide 6/Halloysite Nanotubes Nanocomposites. Polym. J. 41, 835, 2009.

21. WAN X., ZHAN Y., ZENG G., HE Y. Nitrile functionalized halloysite nanotubes/poly(arylene ether nitrile) nanocomposites: Interface control, characterization and improved properties. Appl. Surf. Sci. 393, 1, 2017.

22. DENG S., ZHANG J., LIN Y. Halloysite-epoxy nanocomposites with improved particle dispersion through ball mill homogenisation and chemical treatments. Comp. Sci. Technol. 69 (14), 2497, 2009.

23. TANG Y., DENG S., YE L., YANG C., YUAN Q., ZHANG J., ZHAO C. Effects of unfolded and intercalated halloysites on mechanical properties of halloysite - epoxy nanocomposites. Composites: Part A., Appl. Sci. Manuf. 42 (4), 345, 2011.

24. LIU M., DAI L., SHI H., XIONG S., ZHOU C. In vitro evaluation of alginate/halloysite nanotube composite scaffolds for tissue engineering. Mater. Sci. Eng. 49, 700, 2015.

25. LIU Y., YAN C., ZHANG Z., WANG H., ZHOU S., ZHOU W. A comparative study on fly ash, geopolymer and faujasite block for $\mathrm{Pb}$ removal from aqueous solution. Fuel 185, 181, 2016.

26. LI C., SUN H., LI L. A review: the comparison between alkali-activated slag $(\mathrm{Si}+\mathrm{Ca})$ and metakaolin $(\mathrm{Si}+\mathrm{Al})$ cements. Cem. Concr. Res. 40 (9), 1341, 2010.

27. LIU C., LUO Y.F., JIA Z.X., ZHONG B.C., LI S.Q., GUOL B.C., JIA D.M. Enhancement of mechanical properties of poly(vinyl chloride) with polymethyl methacrylategrafted halloysite nanotube. Express Polym. Lett. 5 (7), 591, 2011.

28. SAIF J.M, ASIF H.M., NAVEED M. Properties and modification methods halloysite nanotubes: a state-of-theart review. J. Chil. Chem. Soc. 63 (3), 4109, 2018.

29. CATALDO S., MURATORE N., ORECCHIO S., PETTIGNANO A. Enhancement of adsorption ability of calcium alginate gel beads towards $\mathrm{Pd}(\mathrm{II})$ ion. A kinetic and equilibrium study on hybrid Laponite and Montmorillonite-alginate gel beads. Appl. Clay Sci. 118, $162,2015$.

30. CATALDO S., LAZZARA G., MASSARO M., MURATORE N., PETTIGNANO A., RIELA S. Functionalized halloysite nanotubes for enhanced removal of lead(II) ions from aqueous solutions. Appl. Clay Sci. 156 (9), 87, 2018.

31. DONG Y., LIU Z., CHEN L. Removal of Zn(II) from aqueous solution by natural halloysite nanotubes. J. Radioanal. Nucl. Chem. 292, 435, 2012.

32. JINHUA W., XIANG Z., BING Z., YAFEI Z., RUI Z., JINDUN L., RONGFENG C. Rapid adsorption of $\mathrm{Cr}(\mathrm{VI})$ 
on modified halloysite nanotubes. Desalination 259 (1), 22, 2010.

33. MELLOUK S., CHERIFI, S. SASSI M., MAROUFKHELIFA K., BENGUEDDACH A., SCHOTT J., KHELIFA A. Intercalation of halloysite from Djebel Debagh (Algieria) and adsorption of cooper ions. Appl. Clay Sci. 44 (3-4), 230, 2009.

34. OTUNOLA B.O., OLOLADE O.O. A review on the application of clay minerals as heavy metal adsorbents for remediation purposes. Environ. Technol. Innovation 18, 100692, 2020.

35. DAVIDOVITS J. Geopolymers and geopolymeric materials. J. Therm. Anal. 35, 429, 1998.

36. DUXON P., FERNANDEZ-JIMENEZ A., PROVIS J.L., LUKEY G.C., PALOMO A., VAN DEVENTER J.S.J. Geopolymer technology: the current state of the art. J. Mater. Sci. 42, 2917, 2007.

37. FAHEEM M.T.M., ABDULLAH M.M.A., HUSSIN K., BINHUSSAIN M., GHAZALI C.M.R., IZZAT A.M. Application of Clay - Based Geopolymer in Brick Production: A Review. Advan. Mater. Res. 626, 878, 2013.

38. HE J., ZHANG J.., YU Y., ZHANG G. The strength and microstructure of two geopolymers derived from metakaolin and red mud-fly ash admixture: A comparative study. Constr. Build. Mater. 30, 80, 2012.

39. SITARZ-PALCZAK E., KALEMBKIEWICZ J., D GALAS D. Comparative study on the characteristics of coal fly ash and biomass ash geopolymers. Archiv. Environ. Protection 45 (1), 126, 2019.

40. SARKER P.K., RANGAN B.V. Geopolymer Concrete Using Fly Ash, in: Sarker P.K. (ed.), Fly Ash: Sources, Applications and Potential Environmental Impacts. Nova Science Publications Inc., New York, 271, 2014.

41. PETERMANN J.C., SAEED A., HAMMONS M.I. Alkali-activated geopolymers: A literature review. Air Force Research Laboratory Materials and Manufacturing Directorate. Technical Report 88, 2010.

42. KAZE C.R., TCHAKOUTEA H.K., MBAKOP T.T., MACHE J.R., KAMSEU E., MELO U.C., LEONELLI C., RAHIERD H. Synthesis and properties of inorganic polymers (geopolymers) derived from Cameroonmetahalloysite. Ceram. Int. 44 (15), 18499, 2018.

43. DAVIDOVITS J., COMRIE D. Long Term Durability of Hazardous Toxic and Nuclear Waste Disposals. Geopolymer 1, 125, 1988.

44. AL-MASHQBEH A., ABUALI S., EL-ESWED B., KHALILI F.I. Immobilization of toxic inorganic anions $\left(\mathrm{Cr}_{2} \mathrm{O}_{7}^{2-}, \mathrm{MnO}_{4}^{-}\right.$and $\mathrm{Fe}(\mathrm{CN})_{6}^{3-}$ in metakaolin based geopolymers: A preliminary study. Ceram. Int. 44 (5), 5613, 2018.

45. FEMINA C.C., KUMAR P.S., SARAVANAN A., JOSHIBA G.J., NAUSHAD M. Efficient techniques for the removal of toxic heavy metals from aquatic environment: A review. J. Environ. Chem. Eng. 5 (3), 2782, 2017.

46. ZHANG J., PROVIS J.L., FENG D., DEVENTER J.S.J. Geopolymers for immobilization of $\mathrm{Cr}^{6+}, \mathrm{Cd}^{2+}$, and $\mathrm{Pb}^{2+}$. $\mathrm{J}$. Hazard. Mater. 157 (2-3), 587, 2008.

47. TAVOR D., WOLFSON A., SHAMAEV A. Recycling of industrial wastewater by its immobilization in geopolymer cement. Ind. Eng. Chem. Res. 46 (21), 6801, 2007.

48. KIM D., PETRISOR I.G., YEN T.F. Geopolymerization of biopolymers: a preliminary inquiry. Carbohydr. Polym. 56 (2), 213, 2004.

49. KALEMBKIEWICZ J., SITARZ-PALCZAK E. Efficiency of leaching tests in the context of the influence of fly ash on the environment. J. Ecol. Eng. 16 (1), 67, 2015.
50. KANI E.N., ALLAHVERDI A., PROVIS J.L. Efflorescence control in geopolymer binders based on natural pozzolan, Cem. Concr. Compos. 34 (1), 25, 2012.

51. GARCÍA R. PIZARRO C., ÁlVAREZ A., LAVÍN A.G., BUENO J.L. Study of biomass combustion wastes. Fuel 148, 152, 2015.

52. PU S., DUAN P., YAN C., REN D. Influence of sepiolite addition on mechanical strength and microstructure of fly ash-metakaolin geopolymer paste. Adv. Powder Technol. 27 (6), 2470, 2016.

53. ALEHYEN S., ZERZOURI M., ELALOUANI M., EL ACHOURI, M., TAIBI M. Porosity and fire resistance of fly ash based geopolymer. J. Mater. Environ. Sci. 8 (10), 3676, 2017.

54. BORDEEPONG S., BHONGSUWAN D., PUNGRASSAMI T., BHONGSUWAN T. Characterization of halloysite from Thung Yai District, Nakhon Si Thammarat Province, in Southern Thailand Songklanakarin J. Sci. Technol. 33 (5), 599, 2011.

55. ZHANG Z., WANG H., PROVIS J.L., BULLEN F., REID A., ZHU Y. Quantitative kinetic and structural analysis of geopolymers. Part 1. The activation of metakaolin with sodium hydroxide. Thermochim. Acta 539, 23, 2012.

56. SITARZ-PALCZAK E., KALEMBKIEWICZ J., D GALAS D. Synthesis of geopolymers on fly ash from biomass combustion, in: CEST 2017 Proceedings [online], $15^{\text {th }}$ International Conference on Environmental Science And Technology, Rhodes, Greece, $31^{\text {st }}$ August - $2^{\text {nd }}$ September 2017. http://www.CEST201700649 (accessed 10 January 2021).

57. BRYLEWSKA K., ROŻEK P., KRÓL M., MOZGAWA W. The influence of dealumination/desilication on structural properties of metakaolin-based geopolymers. Ceram. Int. 44 (11), 12853, 2018.

58. HEAH C.Y., KAMARUDIN H., AL BAKRI A.M., BNHUSSAIN M., LUQMAN M., KHAIRUL NIZAR I., RUZAIDI C.M., LIEW Y.M. Study on solids-to-liquid and alkaline activator ratios on kaolin-based geopolymers. Constr. Build. 35, 912, 2012.

59. HEATH A., PAINE K., MCMANUS M. Minimising the global warming potential of clay based geopolymers. J. Cleaner Prod. 78, 75, 2014.

60. FERONE C., COLANGELO F., ROVIELlO G., ASPRONE D., MENNA C., BALSAMO A., PROTA A., CIOFFI R., MANFREDI G. Application-oriented chemical optimization of a metakaolin based geopolymer. Materials 6 (5), 1920, 2013.

61. LOUA S., BAKLOU S., SAMET B. Geopolymers based on phosphoric acid and illito-kaolinitic clay. Adv. Mater. Sci. Eng. 7, 1, 2016.

62. NORKHAIRUNNISA M., FARIZ M. Geopolymer: A review on physical properties of inorganic aluminosilicate coating materials. Mater. Sci. Forum 803, 367, 2014.

63. VU T.H., GOWRIPALAN N. Mechanisms of heavy metal immobilization using geopolymerisation techniques - a review. J. Adv. Concr. Technol. 16 (3), 124, 2016.

64. RICHARDSON I.G. The calcium silicate hydrates. Cem. Concr. Res. 38 (2), 137, 2008.

65. AKONO A.T., KORIC S., KRIVEND W.M. Influence of pore structure on the strength behavior of particle- and fiberreinforced metakaolin-based geopolymer composites. Cem. Concr. Comp. 104, 103361, 2019.

66. KRIVEN W.M., BELL J.L., GORDON M. Microstructure and microchemistry of fully-reacted geopolymers and geopolymer matrix composites. Ceram. Trans. 153, 227, 2004. 
67. LUUKKONEN T., RUNTTI H., NISKANEN M., TOLONEN E., SARKKINEN M., KEMPPAINEN K., RÄMÖ J., LASSI U. Simultaneous removal of Ni(II), $\mathrm{As}(\mathrm{III})$, and $\mathrm{Sb}(\mathrm{III})$ from spiked mine effluent with metakaolin and blast-furnace-slag geopolymers, J. Environ. Manag. 166, 579, 2016.

68. GAO K., LIN K.L., WANG D., HWANG C.L., SHIU H.S., CHANG Y.M., CHENG T.W. Effects $\mathrm{SiO}_{2} / \mathrm{Na}_{2} \mathrm{O}$ molar ratio on mechanical properties and the microstructure of nano- $\mathrm{SiO}_{2}$ metakaolin-based geopolymers. Constr. Build. Mater. 53, 503, 2014.

69. LIM S., PARK S., SOHN D. Modification of halloysite nanotubes for enhancement of gas-adsorption capacity. Clays and Clay Miner. 68, 189, 2020.

70. NASAB G.M., GOLESTANIFARD F., MACKENZIE K.J.D. The effect of the $\mathrm{SiO} 2 / \mathrm{Na} 2 \mathrm{O}$ ratio in the structural modification of metakaolin-based geopolymers studied by XRD, FTIR and MAS-NMR. J. Ceram. Sci. Technol. 5 (3), 185, 2014.

71. PHAIR J.W., DEVENTER J.S.J. Effect of the silicate activator $\mathrm{pH}$ on the microstructural characteristics of waste-based geopolymers. Int. J. Miner. Eng. 66 (1-4), 121, 2002.

72. COATES J. Interpretation of infrared spectra. A practical Approach. in: Meyers R.A. (ed.) Encyclopedia of Analytical Chemistry, John Wiley\&Sons, New York, 10815, 2011.

73. KRÓL M., ROŻEK P., CHLEBDA D., MOZGAWA W. Influence of alkali metal cations/type of activator on the structure of alkali-activated fly ash - ATR-FTIR studies. Spectrochim. Acta Part A: Molecular and Biomolecular Spectroscopy 198, 33, 2018.

74. SAKLAR S., YORUKOGLU A. Effects of acid leaching on halloysite. Physicochem. Probl. Miner. Process. 51 (1), 83, 2015.

75. EL-ESWED B., YOUSEF R., ALSHAAER M., HAMADNEH I., AL-GHARABLI S., KHALILI F. Stabilization/solidification of heavy metals in kaolin/ zeolite based geopolymers. Int. J. Miner. Process. 137, 34, 2015.

76. EL-ESWED B., ALDAGAG O., KHALILI F. Efficiency and mechanism of stabilization/solidification of $\mathrm{Pb}(\mathrm{II})$, $\mathrm{Cd}(\mathrm{II}), \mathrm{Cu}(\mathrm{II}), \mathrm{Th}(\mathrm{IV})$ and $\mathrm{U}(\mathrm{VI})$ in metakaolin based geopolymers. Appl. Clay Sci. 140, 148, 2017.

77. ZHANG X.Y., CHEN L., KOMARNENI S., ZHOU C.H., TONG D.S., YANG H.M., YU W.H., WANG H. Fly ash-based geopolymer: clean production, properties and applications. J. Cleaner Prod. 125, 253, 2016.
78. SHI C., FERNÁNDEZ-JIMÉNEZ A., Stabilization/ solidification of hazardous and radioactive wastes with alkali-activated cements. J. Hazard. Mater. 137 (3), 1656, 2006.

79. DUAN P., YAN C., ZHOU W., REN D. Development of fly ash and iron ore tailing based porous geopolymer for removal of $\mathrm{Cu}(\mathrm{II})$ from wastewater. Ceram. Int. 42 (12), 13507, 2016.

80. ANDREJKOVIČOVÁ S., SUDAGAR A., ROCHA J., PATINHA C., HAJJAJI W., FERREIRA DA SILVA E., VELOSA A., ROCHA F. The effect of natural zeolite on microstructure, mechanical and heavy metals adsorption properties of metakaolin based geopolymers, Appl. Clay Sci. 126, 141, 2016.

81. CHENG T., LEE M., KO M., UENG T., YANG S. The heavy metal adsorption characteristics on metakaolinbased geopolymer. Appl. Clay Sci. 56, 90, 2012.

82. JAVADIAN H., GHORBANI F., TAYEBI H., ASL S.M.H. Study of the adsorption of Cd(II) from aqueous solution using zeolite-based geopolymer, synthesized from coal fly ash; kinetic, isotherm and thermodynamic studies. Arabian J. Chem. 8 (6), 837, 2015.

83. KARA I., YILMAZER D., AKAR S.T. Metakaolin based geopolymer as an effective adsorbent for adsorption of zinc (II) and nickel (II) ions from aqueous solutions. Appl. Clay Sci. 139, 54, 2017.

84. LEE N.K., KHALID H.R., LEE H.K. Adsorption characteristics of cesium onto mesoporous geopolymers containing nano-crystalline zeolites. Microporous and Mesoporous Mater. 242, 238, 2017.

85. LÓPEZ F., SUGITA S., TAGAYA M., KOBAYASHI T. Metakaolin-based geopolymers for targeted adsorbents to heavy metal ion separation. J. Mater. Sci. Chem. Eng. 2 (7), 16, 2014.

86. NAGHSH M., SHAMS K. Synthesis of a kaolin-based geopolymer using a novel fusion method and its application in effective water softening. Appl. Clay Sci. 146, 238, 2017.

87. SARKAR C., BASU J.K., SAMANTA A.N. Removal of $\mathrm{Ni}^{2+}$ ion from waste water by geopolymeric adsorbent derived from LD Slag. J. Water Process Eng. 17, 237, 2017.

88. SINGHAL A., GANGWAR B.P., GAYATHRY J.M. CTAB modified large surface area nanoporous geopolymer with high adsorption capacity for copper ion removal. Appl. Clay Sci. 150, 106, 2017.

89. MENG Q., CHEN H., LIN J., LIN Z., SUN J. Zeolite A synthesized from alkaline assisted pre-activated halloysite for efficient heavy metal removal in polluted River water and industrial wastewater. J. Environ. Sci. 56, 54, 2017. 